\title{
CRITICAL REVIEW OF SUPERCRITICAL FLUID EXTRACTION OF SELECTED SPICE PLANT MATERIALS
}

\author{
Milan N. Sovilj ${ }^{1}$, Branislava G. Nikolovski' ${ }^{1}$, Momčilo Đ. Spasojević \\ ${ }^{1}$ Faculty of Technology, University of Novi Sad, 21000 Novi Sad, Serbia \\ ${ }^{2}$ Faculty of Technical Sciences, University of Novi Sad, 21000 Novi Sad, Serbia \\ miso@uns.ac.rs // barjakb@uns.ac.rs//momcilos@uns.ac.rs
}

\begin{abstract}
Supercritical fluid extraction (SFE) is one of the relatively new efficient separation method for the extraction of essential oils from different plant materials. The new products, extracts, can be used as a good base for the production of pharmaceutical drugs and additives in the perfume, cosmetic, and food industries. The aim of this work was to analyze the supercritical carbon dioxide extraction ( $\left.\mathrm{SC}_{-} \mathrm{CO}_{2}\right)$ of oils from the selected spice plant materials. In this paper the process parameters such as pressure, temperature, solvent flow rate, size of grinding materials, and ratio of the co-solvent were presented for the selected spice plant materials: black pepper, caraway, celery, cinnamon, clove, coriander, daphne, fennel, ginger, hyssop, juniper, lavender, oregano, pennyroyal, red pepper, safflower, sage, turmeric, and vanilla. The values of operating conditions were: pressure from 7.5 to $68 \mathrm{MPa}$, temperature from 293 to $363 \mathrm{~K}$, solvent flow rate from 0.003 to $30.0 \mathrm{~kg} / \mathrm{h}$, and diameter of grinding material from 0.17 to $3.90 \mathrm{~mm}$. The global yield and quality of the extracts all of the plant material investigated, as well as the possibility of their application in the food, cosmetics and pharmaceutical industries were analyzed. The composition of the extracts was wery complex, and in every case the extract was composed of more than 200 components. All the compounds from the $\mathrm{CO}_{2}$ extracts were classified in the following groups: monoterpene, sesquiterpene, oxygenated monoterpene, and oxygenated sesquiterpene and other hydrocarbon groups. In some of the systems investigated the different mathematical models (Sovová, Hong), which have taken from the literature, were used to correlate the experimental data.
\end{abstract} tion yield

Keywords: supercritical fluid extraction; spice plant materials; process parameters; global extrac-

\section{КРИТИЧКИ ПРЕГЛЕД НА СУПЕРКРИТИЧНА ФЛУИДНА ЕКСТРАКЦИЈА НА ИЗБРАНИ ЗАЧИНСКИ РАСТИТЕЛНИ МАТЕРИЈАЛИ}

\footnotetext{
Суперкритичната флуидна екстракција (SFE) е релативно нова и ефикасна сепарациона метода за екстракција на етерични масла од зачински растителни материјали. Новите продукти, екстракти, можат да се користат како добра основа за производство на фармацевтски препарати и адитиви во индустриите за парфеми, козметика и храна. Целта на овој труд е да се анализира суперкритичната екстракција со јаглероден диоксид $\left(\mathrm{SC}-\mathrm{CO}_{2}\right)$ од масла од избрани зачински растителни материјали. Во овој труд се изнесени работните параметри како што се притисок, температура, брзина на проток на растворувач, големина на мелен материјал и однос на корастворувач за следните зачински растителни материјали: црн пипер, ким, целер, цимет, каранфилче, коријандер, лавор, морач, ѓумбир, изоп, смрека, лаванда, оригано, ситнолисно нане, црвен пипер, шафран, жалфија, куркума и ванила. Вредностите на работните параметри беа: притисок од 7,5 до $68 \mathrm{MPa,} \mathrm{температура} \mathrm{од} 293$ до $363 \mathrm{~K}$, брзина на проток на растворувачот од 0,003 до $30,0 \mathrm{~kg} / \mathrm{h}$ и дијаметар на мелениот материјал од 0,17 до 3,90 mm. Општо земено, беше следен приносот и квалитетот на екстрактот од целиот испитуван
} 
материјал, како и можноста за негова примена во индустријата за храна, козметика и фармација. Составот на екстрактите е многу комплексен и секој од нив содржи повеќе од 200 компоненти. Сите супстанции од екстрактите на $\mathrm{CO}_{2}$ беа класифицирани во следните групи: монотерпени, сесквитерпени, кислородни сесквитепрени и други јаглеводородни соединенија. Различните математички модели (Sovová, Hong) земени од литературата беа искористени за корелирање на експерименталните податоци за некои од испитуваните системи.

Клучни зборови: суперкритична флуидна екстракција; зачински растителни материјали; работни параметри; вкупен принос од екстракција

\section{INTRODUCTION}

Extracts of aromatic herbs, spices, and medicinal plants are used in food and pharmaceutical processing to impart flavor or other functional properties, as well as ingredients in the pharmaceutical products. It is important to account naturally occurring antioxidants, not only to prevent food degradation, but also to formulate functional mixtures for use by the pharmaceutical and cosmetic industries. Use of supercritical fluid extraction (SFE) under different conditions can allow selecting the extraction of different constituents.

Traditionally, volatile essential oils from plant materials are obtained by hydrodistillation (steam, water, or combined steam and water), and this process can be charged by issues like hydrolytical reactions, chemical alteration and thermal degradation of products. One of the main disadvantages of the hydrodistillation method is that essential oils suffer chemical alteration and the heat-sensitive compounds can easily be destroyed. The extract obtained by organic solvents (e.g., hexane, dichloromethane, dichloroethane, etc.) extraction is called oleoresin and contains all the ingredients that are soluble in the organic solvent, including the volatile oils and the resins. Unfortunately, organic solvent extraction of plant materials, such as spices may lead to oxidation of aroma and coloring compounds, especially in the presence of air. However, the use of organic solvents causes also a high energy costs and safety hazards. The SFE has found applications in the extraction of flavors and fragrances from their natural sources and as a result many studies have been published using this environmentally friendly extraction method. SFE as an alternative process to conventional solvent extraction and steam distillation for essential oils has great potential use especially in food, cosmetic and pharmaceutical industries. Processing media such as carbon dioxide, water, and ethanol under pressure, offer a safe and effective way of extracting, refining, and concentrating extracts for the market. Fluid-phase extraction with a solvent in a near critical state (sub- or supercritical fluid), is an energy efficient, environmentally friendly alternative to the traditional methods for isolation of natural products for nutraceutical and pharmaceutical ingredients. Among several possible fluids, carbon dioxide $\left(\mathrm{CO}_{2}\right)$ is the most exploited one, since it is gentle-natured solvent, since its critical point (304 K, 7.4 Mpa) allows low temperature extraction conditions, consequently avoiding thermal degradation of a product; additionally $\mathrm{CO}_{2}$ is inexpensive, and readily available [1]. Carbon dioxide and the extract are easily separated by the pressure reduction behind the extractor, and contrary to the conventional solvent extraction product, the extract is free of any undesirable solvent without time and energy consuming additional separation processes. The low viscosity and high diffusivity of the supercritical fluid enhance the penetrating power based in the high mass transfer rate of the solutes into the fluid, allowing an efficient extraction of the compounds from the raw material. Moreover, low viscosity contributes to the lower fluid transportation costs. The extracts from SFE are free of solvent residues, and the process can be conducted at low temperature, which is very 
important to thermo-liable materials because the high temperature could devalue the products from it.

However, like any other $\mathrm{CO}_{2}$ in supercritical conditions as a solvent can not be effectively utilized for all tasks, and is a poor solvent for polar compounds. For certain applications, the addition of a minimal amount of a polar co-solvent/entrainer suffices to improve the extraction of targeted components from a natural product matrix, such as water, ethanol, methanol, acetic acid, and ethylene glycol.

Spices may be defined as a class of strongly flavored or aromatic substances obtained from plants, commonly used as condiments and utilized for their flavor and preservative qualities. Both individual spice extracts and their formulations are used not only to camouflage undesirable odors in food, but also to add flavor to stimulate appetite and to imbibe preservative and therapeutic values in food, soft drinks, beverages, confectioneries, and health tonics [2]. There is hardly any spice which does not have at least some medicinal effect and therapeutic benefits based upon the number of bioactive components present, pertaining to particular biological actions. Most commonly used spices are all proven to be medicinal, for example, black pepper, thyme, juniper, cayenne, cinnamon, garlic, ginger, licorice, onion, chives, etc. [2].

There are at least two kinds of spice extracts: the one responsible for aroma or flavor, called an essential oil or simply essence; and the other, a higher boiling fraction responsible for taste or pungency of the spice, called oleoresin [2]. Essential oils represent a small fraction of a plant's composition but confer the characteristics for wich aromatic plants are used in the pharmceutical, food and fragrance industries. Essential oils have complex composition, containing from a few dozen to several hundred compounds, especially hydrocarbons (terpenes and sesquiterpenes), and oxygenated compounds (alcohols, aldehydes, ketones, acids, phenols, oxides, lactones, acetals, ethers and esters). Both hydrocarbons and oxygenated components are responsible for the characteristic odours and flavours.
The purpose of this work is to enlighten the state of the art in the field of supercritical fluid extraction of spice plant materials. Main characteristics and usage of the most prominent spices are listed, supercritical fluid extraction process characteristics are emphasized, and the literature review of the SFE of spices are given.

\section{REVIEW OF EXPERIMENTAL DATA AND ANALYSIS}

The extraction yield $(Y)$ in supercritical carbon dioxide extraction $\left(\mathrm{SC}-\mathrm{CO}_{2}\right)$ was calculated by equation:

$$
Y=\frac{m_{\text {ext }}}{m_{\text {mat }}} \times 100, \%
$$

where: $m_{\text {ext }}-$ mass of extract, $m_{\text {mat }}-$ mass of raw material.

This review provides a detailed and updated discussion of applications of SC- $\mathrm{CO}_{2}$ extraction in the isolation of essential oils and oleoresins from selected spices. SC- $\mathrm{CO}_{2}$ extraction has been compared with conventional extraction methods in terms of selectivity, and possibility of manipulating the composition of the extract. State of the art in a rapidly developing field of supercritical fluid extraction of spices is summarized in the following text.

Black pepper (Piper nigrum L.) is perennial woody vine from the Piperaceae familly. The content of essential oil from pepper is 2 to $4.5 \%$ $(w / w)$ and it has been found to consist mainly of monoterpenes and sesquiterpenes. Several authors investigated the supercritical extraction of black pepper [3-5]. Ferreira et al. [3] studied a fixed bed extraction of black pepper essential oil using supercritical $\mathrm{CO}_{2}$ as a solvent. Experiments were carried out at temperatures of 303,313 , and $323 \mathrm{~K}$, and pressures of 15,20 , and $30 \mathrm{MPa}$. The process parameters, as well as a content of oil in the feed and extraction yield for all the spice materials analyzed in this paper is shown in Table 1. 
T a b l e 1

Amount of oil in the feed and process parameters in supercritical carbon dioxide extraction of the selected oil seeds

( $P$ - pressure; $T$ - temperature; $M, V$ - solvent flow rate; $\mathrm{d}_{\text {av }}$ - average diameter of grinding materials; $v$ - superficial velocity of solvent; $W$ - moisture content).

\begin{tabular}{|c|c|c|c|c|}
\hline Spice material & $\begin{array}{l}\text { Amount of } \\
\text { oil in the } \\
\text { feed, } \\
\%(w / w)\end{array}$ & Process parameters & $\begin{array}{l}\text { Global } \\
\text { extraction } \\
\text { yield, } \\
\%(w / w)\end{array}$ & Ref. \\
\hline \multirow{3}{*}{$\begin{array}{l}\text { Black pepper } \\
\text { (Piper nigrum L.) }\end{array}$} & $1.45-3.46$ & $P=15-30 \mathrm{MPa} ; T=303-323 \mathrm{~K}$ & 2.05 & {$[3]$} \\
\hline & 1.5 & $\begin{array}{l}P=9-15 \mathrm{MPa} ; T=313-323 \mathrm{~K} \\
M=1.0-3.0 \mathrm{~kg} / \mathrm{h} ; d_{\mathrm{av}}=0.175 \mathrm{~mm}\end{array}$ & 13.2 & {$[4]$} \\
\hline & 6.2 & $\begin{array}{l}P=16-26 \mathrm{MPa} ; T=308-323 \mathrm{~K} ; V=0.2-0.4 \mathrm{~m}^{3} / \mathrm{h} \\
d_{\mathrm{av}}=20-50 \text { meshes }\end{array}$ & 6.2 & {$[5]$. } \\
\hline \multirow{3}{*}{$\begin{array}{l}\text { Caraway } \\
\text { (Carum carvi } \mathrm{L} .)\end{array}$} & $3.0-7.0$ & $P=7.5-30 \mathrm{MPa} ; \mathrm{T}=305-348 K ; M=4.0 \mathrm{~kg} / \mathrm{h}$ & 7.5 & {$[7]$} \\
\hline & - & $P=20.8 \mathrm{MPa} ; T=297-333 \mathrm{~K}$ & - & {$[8]$} \\
\hline & - & $P=9 \mathrm{MPa} ; T=323 \mathrm{~K}$ & - & {$[9]$} \\
\hline \multirow{3}{*}{$\begin{array}{l}\text { Celery } \\
\text { (Apium graveolens L.) }\end{array}$} & - & $P=10-20 \mathrm{MPa} ; T=318-327 \mathrm{~K}$ & - & {$[10]$} \\
\hline & 3.0 & $P=14-35 \mathrm{MPa} ; T=313 \mathrm{~K} ; M=1.5 \mathrm{~kg} / \mathrm{h}$ & 6.0 & {$[11]$} \\
\hline & - & $P=22-25 \mathrm{MPa} ; T=308-313 \mathrm{~K} ; M=1.5 \mathrm{~kg} / \mathrm{h}$ & 1.65 & {$[12]$} \\
\hline \multirow{3}{*}{$\begin{array}{l}\text { Cinnamon } \\
\text { (Cinnamomum verum, } \\
\text { synonym } \\
\text { C. zeylanicum) }\end{array}$} & 3.0 & $\begin{array}{l}P=9-12 \mathrm{MPa} ; T=313-323 \mathrm{~K} ; M=6.0 \mathrm{~kg} / \mathrm{h} ; \\
\mathrm{d}_{a v}=0.3-0.8 \mathrm{~mm} ; W=10.0 \%(\mathrm{w} / \mathrm{w})\end{array}$ & 0.78 & [13] \\
\hline & - & $P=35 \mathrm{MPa} ; T=313 \mathrm{~K} ; M=30 \mathrm{~kg} / \mathrm{h}$ & - & {$[14]$} \\
\hline & - & $\begin{array}{l}P=22.5 \mathrm{MPa} ; T=323 \mathrm{~K} ; d_{\mathrm{av}}=0.3 \mathrm{~mm} \\
V=9.0 \cdot 10^{-3} \mathrm{~m}^{3} / \mathrm{h}\end{array}$ & - & {$[15]$} \\
\hline \multirow{3}{*}{$\begin{array}{l}\text { Clove bud } \\
\text { (Syzygium aromati- } \\
\text { cum) }\end{array}$} & 15.5 & $\begin{array}{l}P=8-20 \mathrm{MPa} ; T=313-323 \mathrm{~K} \\
M=0.6-1.2 \mathrm{~kg} / \mathrm{h} ; d_{\mathrm{av}}=0.33-0.35 \mathrm{~mm}\end{array}$ & 19.0 & [16] \\
\hline & - & $P=10-30 \mathrm{MPa} ; T=303-323 \mathrm{~K}$ & 23.95 & {$[17]$} \\
\hline & - & $P=11-19 \mathrm{MPa} ; T=325-416 \mathrm{~K}$ & - & {$[18]$} \\
\hline \multirow{4}{*}{$\begin{array}{l}\text { Coriander } \\
\text { (Coriandrum sativum } \\
\text { L.) } \\
\text { family Umbelliferae }\end{array}$} & 0.65 & $P=15 \mathrm{MPa} ; \mathrm{T}=323 \mathrm{~K} ; V=3.0 \cdot 10^{-3} \mathrm{~m}^{3} / \mathrm{h}$ & 0.61 & {$[19]$} \\
\hline & - & $P=20-30 \mathrm{MPa} ; 308 \mathrm{~K}$ & - & {$[20]$} \\
\hline & - & $\begin{array}{l}P=9-15 \mathrm{MPa} ; T=313-323 \mathrm{~K}, d_{\mathrm{av}}=0.4-0.8 \mathrm{~mm} \\
M=0.79-1.56 \mathrm{~kg} / \mathrm{h}\end{array}$ & - & {$[21]$} \\
\hline & - & $P=11.6-28 \mathrm{MPa} ; T=311-331 \mathrm{~K}$ & - & {$[22]$} \\
\hline \multirow{2}{*}{$\begin{array}{l}\text { Daphne } \\
\text { (Laurus nobilis L.) }\end{array}$} & $14-28$ & $P=14-68 \mathrm{MPa} ; T=348 \mathrm{~K} ; d_{\mathrm{av}}=0.17 \mathrm{~mm}$ & 27.5 & [23] \\
\hline & & $P=9-25 \mathrm{MPa} ; T=313 \mathrm{~K}$ & - & {$[24]$} \\
\hline \multirow{4}{*}{$\begin{array}{l}\text { Fenel } \\
\text { (Foeniculum vulgare } \\
\text { Mill.) }\end{array}$} & - & $P=8.2-8.4 \mathrm{MPa} ; T=304-308 \mathrm{~K} ; V=2 \cdot 10^{-3} \mathrm{~m}^{3} / \mathrm{h}$ & - & {$[25]$} \\
\hline & - & $P=8.0-15.0 \mathrm{MPa} ; T=313-330 \mathrm{~K} ; M=0.2 \mathrm{~kg} / \mathrm{h}$ & 5.5 & {$[26]$} \\
\hline & - & $\begin{array}{l}P=9-20 \mathrm{MPa} ; T=313-323 \mathrm{~K} \\
M=0.5-1.5 \mathrm{~kg} / \mathrm{h} ; d_{\mathrm{av}}=0.37 \mathrm{~mm}\end{array}$ & - & [27] \\
\hline & - & $P=20.65-36.14 \mathrm{MPa} ; T=318-328 \mathrm{~K}$ & - & [28] \\
\hline
\end{tabular}




\begin{tabular}{|c|c|c|c|c|}
\hline \multirow{3}{*}{$\begin{array}{l}\text { Hyssop } \\
\text { (Hyssopus officinalis) }\end{array}$} & - & $P=10 \mathrm{MPa} ; T=313 \mathrm{~K}$ & 2.29 & [29] \\
\hline & - & $P=10.13-35.46 \mathrm{MPa} ; T=308-348 \mathrm{~K}$ & 2.1 & {$[30]$} \\
\hline & - & $\begin{array}{l}P=9-10 \mathrm{MPa} ; T=313-323 \mathrm{~K} \\
M=0.0212-0.022 \mathrm{~kg} / \mathrm{min} ; d_{\mathrm{av}}=0.3-0.8 \mathrm{~mm} .\end{array}$ & - & {$[31]$} \\
\hline \multirow{2}{*}{$\begin{array}{l}\text { Ginger } \\
\text { (Zingiber officinale } \\
\text { Roscoe) }\end{array}$} & - & $\begin{array}{l}P=20-25 \mathrm{MPa} ; T=298-308 \mathrm{~K} ; \\
M=0.2034-0.2167 \mathrm{~kg} / \mathrm{h} ; W=17.0 \%(w / w)\end{array}$ & 2.65 & {$[32]$} \\
\hline & 3.0 & $\begin{array}{l}P=15-25 \mathrm{MPa} ; T=293-313 \mathrm{~K} \\
M=0.2016 \mathrm{~kg} / \mathrm{h} ; W=14.0 \%(w / w)\end{array}$ & - & {$[33]$} \\
\hline \multirow{3}{*}{$\begin{array}{l}\text { Juniper } \\
\text { (Juniperus communis } \\
\text { L., } \\
\text { family Cupressaceae) }\end{array}$} & $0.2-3.42$ & $\begin{array}{l}P=8-20 \mathrm{MPa} ; T=313 \mathrm{~K} \\
M=0.2 \mathrm{~kg} / \mathrm{h} ; d_{\mathrm{av}}=0.25-0.40 \mathrm{~mm}\end{array}$ & $0.65-4.0$ & [34-38] \\
\hline & - & $P=20-30 \mathrm{MPa} ; T=323 \mathrm{~K}$ & - & Bruno \\
\hline & - & $P=9-20 \mathrm{MPa} ; T=313 \mathrm{~K} ; M=0,4 \mathrm{~kg} / \mathrm{h}$ & - & Skala \\
\hline \multirow{3}{*}{$\begin{array}{l}\text { Lavender flowers ( La- } \\
\text { vandula angustifolia) }\end{array}$} & - & $P=8-12 \mathrm{MPa} ; T=308-333 \mathrm{~K}$ & 4.9 & {$[41]$} \\
\hline & - & $P=8-12 \mathrm{MPa} ; T=308-333 \mathrm{~K}$ & - & {$[42]$} \\
\hline & - & $\begin{array}{l}P=8-14 \mathrm{MPa} ; T=308-323 \mathrm{~K} \\
M=0.06552-0.1310 \mathrm{~kg} / \mathrm{h}\end{array}$ & - & {$[43]$} \\
\hline \multirow{3}{*}{$\begin{array}{l}\text { Oregano } \\
\text { (Origanum majorana } \\
\text { L.) }\end{array}$} & - & $P=45 \mathrm{MPa} ; T=323 \mathrm{~K} ; M=7.0 \mathrm{~kg} / \mathrm{h}$ & 3.8 & {$[44]$} \\
\hline & - & $P=10-20 \mathrm{MPa} ; T=298-318 \mathrm{~K}$ & - & {$[45]$} \\
\hline & - & $P=10-40 \mathrm{MPa} ; T=313-333 \mathrm{~K}$ & - & {$[46]$} \\
\hline \multirow{2}{*}{$\begin{array}{l}\text { Pennyroyal } \\
\text { (Mentha piperita L.) }\end{array}$} & - & $P=10.13-30.39 \mathrm{MPa} ; T=328-363 \mathrm{~K}$ & - & {$[47]$} \\
\hline & - & $\begin{array}{l}P=9-10 \mathrm{MPa} ; T=313-323 \mathrm{~K} \\
M=1.6 \mathrm{~kg} / \mathrm{h} ; W=9.0 \%(w / w)\end{array}$ & - & {$[48]$} \\
\hline \multirow{2}{*}{$\begin{array}{l}\text { Red pepper } \\
\text { (Capsicum annuum L.) }\end{array}$} & - & $P=10-40 \mathrm{MPa} ; T=308-328 \mathrm{~K}$ & 11.5 & {$[49]$} \\
\hline & - & $\begin{array}{l}P=32-54 \mathrm{MPa} ; T=313 \mathrm{~K} ; v=2.052-4.5 \mathrm{~m} / \mathrm{h} \\
d_{\mathrm{av}}=0.273-3.90 \mathrm{~mm} ; W=4.0 \%(w / w)\end{array}$ & 56.0 & {$[50]$} \\
\hline \multirow{2}{*}{$\begin{array}{l}\text { Safflower } \\
\text { (Carthamus tinctorius } \\
\text { L.) }\end{array}$} & 29.0 & $\begin{array}{l}P=22-28 \mathrm{MPa} ; T=308-333 \mathrm{~K} \\
M=0.98-3.74 \mathrm{~kg} / \mathrm{h} ; d_{a v}=0.35-0.85 \mathrm{~mm}\end{array}$ & 28.0 & {$[51]$} \\
\hline & - & $P=9-30 \mathrm{MPa} ; \mathrm{T}=308 K ; M=3.74 \mathrm{~kg} / \mathrm{h}$ & - & {$[52]$} \\
\hline \multirow{2}{*}{$\begin{array}{l}\text { Sage } \\
\text { (Salvia officinalis L.) }\end{array}$} & 2.7 & $\begin{array}{l}P=9-12.8 \mathrm{MPa} ; T=298-323 \mathrm{~K} ; M=0.003-0.021 \\
\mathrm{~kg} / \mathrm{h}\end{array}$ & 4.8 & {$[53]$} \\
\hline & - & $P=10-30 \mathrm{MPa} ; T=323 \mathrm{~K}$ & - & {$[54]$} \\
\hline \multirow{2}{*}{$\begin{array}{l}\text { Turmeric } \\
\text { (Curcuma longa L.) }\end{array}$} & $3.0-6.0$ & $\begin{array}{l}P=30 \mathrm{MPa} ; \mathrm{T}=303 \mathrm{~K} ; M=0.147-0.169 \mathrm{~kg} / \mathrm{h} ; \\
W=66.7 \%(w / w)\end{array}$ & 8.0 & {$[55]$} \\
\hline & - & $P=20-40 \mathrm{MPa} ; T=313-333 \mathrm{~K}$ & - & {$[56]$} \\
\hline \multirow{2}{*}{ Vanilla } & - & $P=10-13 \mathrm{MPa} ; T=306-309 \mathrm{~K} ; M=2-62 \mathrm{~g} \mathrm{CO}_{2} / \mathrm{g}$ & - & {$[57]$} \\
\hline & - & $P=15-24 \mathrm{MPa} ; T=308-328 \mathrm{~K} ; d_{\mathrm{av}}=0.30-0.80 \mathrm{~mm}$ & - & {$[58]$} \\
\hline
\end{tabular}

Solubility of oil increased with increase of the pressure, because of the solvent density increase. It was possible to identify the constant extraction rate period in the extraction curves as well as the failing and diffusion rate period. When the yield of the $\mathrm{SC}-\mathrm{CO}_{2}$ extraction was compared with that of steam distillation it can be concluded that SFE was an ef- ficient process for black pepper oil extraction. Perakis et al. [4] showed the results of the SC$\mathrm{CO}_{2}$ extraction of ground black pepper. They examined effect of process parameters, namely pressure $(9,10,15 \mathrm{MPa})$, temperature $(313$, $323 \mathrm{~K}$ ) on extraction rate. The authors [4] concluded also that oil consists mainly of monoterpenes and sesquiterpenes. Effect of temperature 
on the extraction yield of black pepper versus the specific amount of solvent $(Q)$ at $10 \mathrm{MPa}$ and a solvent flow rate of $2 \mathrm{~kg} \mathrm{CO} / \mathrm{h}$ shown in the Figure 1.

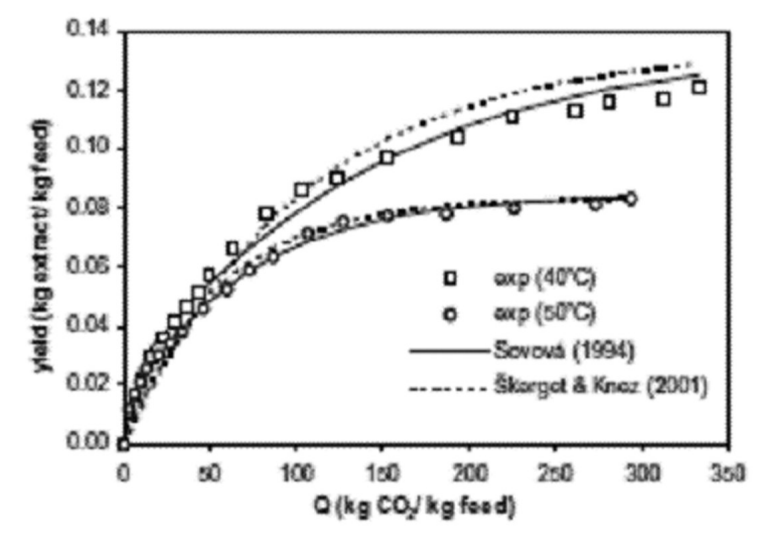

Fig. 1. Effect of temperature on the extraction yield of black pepper versus the specific amount of solvent $(Q)$ at $10 \mathrm{MPa}$, and a solvent flow rate of $2 \mathrm{~kg} \mathrm{CO}_{2} / \mathrm{h}$.

[Source: Perakis et al., J. Food Eng., 71, 386-393 (2005)].

As shown in Figure 1 the temperature increase from 313 to $323 \mathrm{~K}$ at $10 \mathrm{MPa}$, resulted in the decrease of solvent's density, whose effect seems to have dominated over the increase of the solute vapor pressure. Furthermore, the final extraction yield was enhanced by $45 \%$, as temperature decreased. Ferreira et al. [3] studied a fixed bed extraction of black pepper essential oil using SCF and $\mathrm{CO}_{2}$ as a solvent. Experiments were obtained at temperatures of 303,313 , and $323 \mathrm{~K}$, pressures of 15,20 , and $30 \mathrm{MPa}$, and solvent flow rate of 1.1, 2.0, 3.0 $\mathrm{kg} / \mathrm{h}$. The process parameters have different effect on the extraction rate. The extraction rate increases with increasing pressure because of the increase of solvent's density. Thus, at the higher pressure $(15 \mathrm{MPa})$ the pepper oil was extracted faster than at lower pressure (10 $\mathrm{MPa}$ ), but the total amount of extract was almost the same. The minimal extraction yield was obseved at $9 \mathrm{MPa}$ due to the fact that some components, which were extracted at $15 \mathrm{MPa}$, were not soluble in $\mathrm{CO}_{2}$ at $9 \mathrm{MPa}$. The increase of the temperature from 313 to $323 \mathrm{~K}$ caused the decrease of the extraction rate, due to the decrease of solvents density. The increase of the solvent flow rate resulted in the increase of the extraction rate. This effect was more implicited, when the flow rate was increased up to $3 \mathrm{~kg} / \mathrm{h}$. Li et al. [5] investigated $\mathrm{SC}-\mathrm{CO}_{2}$ extraction of black pepper at 16-26 MPa, temperature of 308-323 K, solvent flow rate from $0.2-0.4 \mathrm{~m}^{3} / \mathrm{h}$, and diameter of ground material of 20-50 meshes. They concluded that the extraction rate was higher at higher pressure, because of the fact that at constant temperature, the density of the solvent increases with pressure increase and the vapor pressure of the solute decrease with pressure increase. The extraction rate increases with an increase in temperature at $25 \mathrm{MPa}$ and decreases with an increase in temperature at $10 \mathrm{MPa}$. This behavior could be explained by appearing so call "cross-over" pressure between this two values of pressure, which means that than exists two competing effects of reduction in solvent density and the increase in solute vapor pressure with increase in temperature. The fact is that at lower pressure, the change of the solvent density is more efficient than that of solute vapor pressure, as extraction rate increases with decrease in temperature. However, at higher pressure $(25 \mathrm{MPa})$ the extraction rate is dependent on the solute vapor pressure and it increase with an increase in temperature. The optimal process condition of the supercritical fluid extraction for pepper oil was at 22-26 MPa, $318 \mathrm{~K}$, and $0.3-0.4$ $\mathrm{m}^{3} / \mathrm{h}$. The extraction rate increased with increasing particle size due to intraparticle diffusion resistance was smaller for smaller particle size because of shorter diffusion path. Essential oil obtained by $\mathrm{SC}-\mathrm{CO}_{2}$ extraction had higher levels of sesquiterpenes and monoterpenes. The maximum values of extraction yield (global extraction yield) for most of the systems investigated is shown in the Table 1.

Caraway (Carum carvi L.) is a member of the family of Umbelliferae, which contain considerable amounts of monoterpenes. Caraway is cultivated in the Netherlands, Eastern Europe and Germany, furthermore North Africa. Caraway fruits may contain 3-7\% (w/w) essential oil. The aroma of the oil is mostly dominated by carvone, and limonene [6]. It is known for its extremely ef- 
fective antiflatulent powers, it is carminative and stomakick. Baysal and Starmans [7] optimized the $\mathrm{SC}-\mathrm{CO}_{2}$ extraction of carvone from caraway seed with respect to pressure, temperature, solvent flow rate, and extraction time in order to selectively obtained essential oil. The process parameters were changed in the intervals: pressure (7.5-30 MPa), temperature (305 K), solvent flow rate $(1.0-10.0 \mathrm{~kg} / \mathrm{h})$. It was shown that the highest yield of carvone was obtained at an extraction pressure of $12.5 \mathrm{MPa}$, temperature of $305 \mathrm{~K}$ for less than $45 \mathrm{~min}$, and at a solvent flow rate of 4.0 $\mathrm{kg} / \mathrm{h}$. The data acquired in this research suggested that the density of supercritical $\mathrm{CO}_{2}$ phase was a prime factor for successful extraction. Sovová et al. [8] extracted caraway seeds with liquid and supercritical $\mathrm{CO}_{2}$ at 296-313 K, and 9-10 MPa. The extracts were analyzed for carvone and limonene, and compared with essential oil obtained by steam distillation. Slight fractionation was observed during the extraction. The effect of process parameters, such as temperature, pressure, and solvent flow rate and direction, on essential oil recovery was described using a simple model with mass transfer between a liquid mixture of essential and fatty oils and the solvent, and with diffusion resistances both in the liquid mixture and in the walls of caraway cells. A volatile concentrate of caraway seeds was isolated by supercritical $\mathrm{CO}_{2}$ extraction coupled to a fractional separation technique. $\mathrm{GC} /$ MS analysis of the various fractions obtained at different extraction and fractionation conditions allowed the identification of the operating conditions to isolate the volatile concentrate. A good extraction performance was obtained operating at $9 \mathrm{MPa}$ and $323 \mathrm{~K}$. The optimum fractionation was achieved by operating at $9 \mathrm{MPa}$ and $261 \mathrm{~K}$ in the first separator, and at $1 \mathrm{MPa}$ and $290 \mathrm{~K}$ in the second. The influence of the extraction time on the composition was evaluated. Cabizza et al. [9] isolated a volatile concentrate of caraway seeds by SCE coupled to a fractional separation technique. A comparison with the hydrodistilled oil was also provided.

Celery (Apium graveolens L.) is a spice native in Eurasia that belongs to the family of $\mathrm{Um}^{-}$ belliferae. The leaf and root of celery are used for culinary purposes. Celery essential oil is commercially produced from the seed, and also from the leaf. The essential oil yield from celery seed is commonly $1.5-3.0 \%(w / w)$. Papamichail et al. [10] carried out the $\mathrm{SC}-\mathrm{CO}_{2}$ extraction at a pressure at 10,15 and $20 \mathrm{MPa}$, temperature of 318 and $327 \mathrm{~K}$, solvent flow rate from 1.1 to $3.0 \mathrm{~kg} / \mathrm{h}$, and average diameter of ground materials of 0.21 to $0.49 \mathrm{~mm}$ (Table 1). At higher pressure (20 MPa) the total amount of extract was higher than at lowest pressure $(10 \mathrm{MPa})$ due to the increase of $\mathrm{CO}_{2}$ density and consequently its dissolving ability. On the other size, as temperature increases, the extraction rate decreases, due to the decrease of the solvent density, whose effect seems to dominate over the increase of the solute vapor pressure. Finaly, as the size of the seeds reduces, the extraction rate increases. This can be attributed to the fact that the amount of the oil released by the milling increases as the particle size decreases (Figure 2).

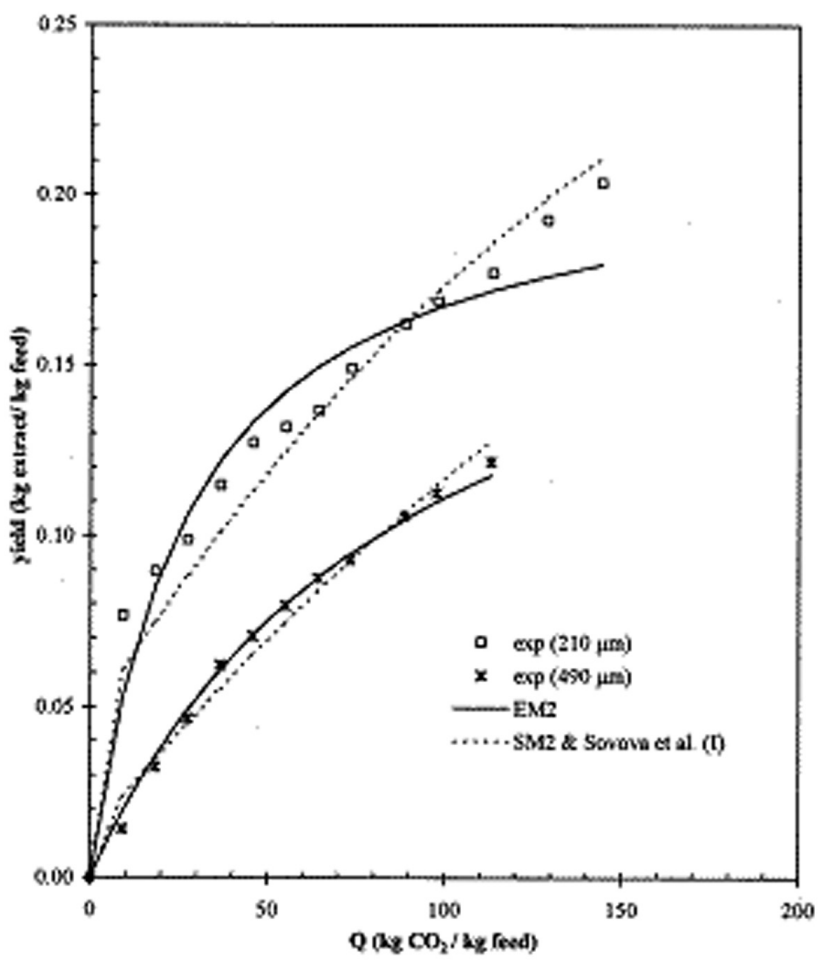

Fig. 2. Effect of particle size of cellery seed on the extraction yield versus specific amount of solvent $(Q)$ at $15 \mathrm{MPa}, 318 \mathrm{~K}$, and a solvent flow rate of $1.1 \mathrm{~kg} \mathrm{CO} / \mathrm{h}$. [Source: Papamichail et al., J. Supercrit. Fluids., 18, 213-226 (2000)]. 
Daukšas et al. [11] presented the results of the $\mathrm{SC}-\mathrm{CO}_{2}$ extraction of different parts of celery at following process parameters: pressure $(14-35 \mathrm{MPa})$, temperature $(308,313 \mathrm{~K})$, and solvent flow rate of $1.5 \mathrm{~kg} / \mathrm{h}$ (Table 1 ). The extraction rate was enhanced by the pressure fluctuation at the beginning of the process, but when $\sim 3 \mathrm{~kg}$ of $\mathrm{CO}_{2}$ were passed through the material the amount of the extract became almost equal both at a constant and fluctuating pressure. The chemical composition of celery extracts obtained at constant and fluctuating pressure showed that linoleic (cis, cis-9,12-octadecadienoic acid) acid was the main constituent in celery extracts. Other important constituents were palmitic acid, stigmasterol, $\beta$-sitosterol and sedanolide. Liu et al. [12] investigated also $\mathrm{SC}-\mathrm{CO}_{2}$ extraction of celery seeds. The optimum technological condition of extracting oil from celery seeds was defined: particle size 60 meshes, temperature $318 \mathrm{~K}$, working pressure $20 \mathrm{MPa}, \mathrm{CO}_{2}$ flow $15 \times 10^{-3} \mathrm{~m}^{3} / \mathrm{h}$, and operating time $2 \mathrm{~h}$.

Cinnamon (Cinnamomum verum, synonym $C$. zeylanicum) is a small evergreen tree belonging to the family of Lauraceae, native to Sri Lanka. Most of the cinnamon oil is produced from leaves, which contains about $1 \%(w / w)$ of oil. However, the root bark yields $3 \%$ oil $(w / w)$. The leaf oil is rich in eugenol and eugenyl acetate, both of which are antioxidants. Bark oil is more valuable than the leaf oil, though both find wide uses in flavoring and pharmaceutical industries. Marongiu et al. [13] exploited $\mathrm{SC}-\mathrm{CO}_{2}$ extraction of Cinnamomum zeylanicum with the aim to investigate their activity. (E)-cinnamaldehyde, $(E)$ - $\beta$-caryophyllene. $\alpha$-terpineol, and eugenol were found to be the major components. They showed the influence process parameters of temperature, pressure, $\mathrm{CO}_{2}$ flow rate and bulk density of the raw material [13]. Factors affecting extraction yields, such as temperature, pressure, $\mathrm{CO}_{2}$ flow rate and bulk density of the raw material, were discussed. Huang et al. [14] studied the extraction of cinnamon oil by supercritical carbon dioxide. By orthogonal experiment, optimal technological conditions were achived as follows: temperature $313 \mathrm{~K}$; extracting pressure $35 \mathrm{MPa}$; solvent flow rate $30 \mathrm{~kg} / \mathrm{h}$; and bulk density of raw material $0.44 \pm 0.02 \mathrm{~g} / \mathrm{ml}$. Oil yield obtained by this method was 5 times more than that by steam distillation. Extraction technique of Chinese cinnamon oil by supercritical carbon dioxide method was also studied. Factors affecting extraction yields, such as temperature, pressure, $\mathrm{CO}_{2}$ flow rate and bulk density of the raw material, were discussed. Oil yield obtained by this method is 5 times higher than that by steam distillation method [15].

Clove bud (Syzygium aromaticum) is a plant that belongs to the family of Myrtaceaea, endemic in the North Moluccas (Indonesia) and on East African islands. Essential oil is produced from the dried flower buds. The content of essential oil in clove buds of good quality may exceed $15 \%(w / w)$. In the hydrodistilled oil the main compounds are eugenol, eugenyl acetate, and $\beta$-caryophyllene. The clove oil has been used widely as pharmaceuticals, flavoring and antimicrobial agents in food industry. Della Porta [16] isolated volatile oil from clove bud by $\mathrm{SC}-\mathrm{CO}_{2}$ extraction coupled to a fractional separation technique (pressure of 8-20 MPa, temperature of $313-323 \mathrm{~K}$, mean particle size of $0.33-0.35 \mathrm{~mm}$, and $\mathrm{CO}_{2}$ flow rates ranging between 0.6 and $1.2 \mathrm{~kg} / \mathrm{h}$ were used). The preliminary studies indicated that $9 \mathrm{MPa}$ and 323 $\mathrm{K}$ were the best extraction conditions, because no undesired compounds were found in the extract except waxes. The extract obtained from clove bud by using supercritical fluid extraction was compared with the essential oil obtained by steam distillation and microwave-assisted extraction by considering both quantity and quality of the product. The oil yield was higher in steam distillation and microwave oven extraction. In contrast, oil extracted by using SFE contained higher amount of eugenol and eugenyl acetate. The presence of waxes is due to the different mass transfer mechanisms that characterize the extraction of terpenes and paraffins. $\mathrm{SC}-\mathrm{CO}_{2}$ extraction of essential oil from clove buds was explored also by Guan et al. [17]. The effect of different parameters, such as temper- 
ature $(303,313,323 \mathrm{~K})$, pressure $(10,20,30$ $\mathrm{MPa})$, and particle size index (0.5223-0.7944), on the extraction yield and the content of eugenol in extracts was investigated using three-level orthogonal array design. It was found from the mathematical analysis that the particle size had the most influence on the oil yield, then the temperature and pressure. Experimental results indicated that the increase of temperature from 303 to $313 \mathrm{~K}$ results in the increase of the extraction yield and high eugenol content in the oils, while the increase of temperature from 303 to $323 \mathrm{~K}$ does not result in the increase of the oil yield, and there is increase of eugenol content in clove oil. The essential oil of $19.56 \%$ $(w / w)$ yield can be extracted from clove buds at pressure of $10 \mathrm{MPa}$ and temperature of 323 $\mathrm{K}$. General characteristics of the clove oils obtained by different methods $\left(\mathrm{SC}-\mathrm{CO}_{2}\right.$ extraction, hydrodistillation, steam distillation and Soxhlet extraction) were compared, and SC$\mathrm{CO}_{2}$ extraction was considered as the optimum process among the four processes for obtaining clove oil with high quality. Yazdani et al. [18] studied the SFE of clove bud essential oil was using $\mathrm{CO}_{2}$ as a solvent. The effect of operating conditions was analyzed in a series of experiments at temperatures between 325 and 416 $\mathrm{K}$ and pressures between 11 and $19 \mathrm{MPa}$. The collected extracts were analyzed and the relative composition of the essential oil was determined. The optimum condition was found in a temperature of $353 \mathrm{~K}$ and at a pressure of 19 $\mathrm{MPa}$, minimizing the number of extracts to two compounds (eugenol and eugenyl acetate). The extract obtained from clove bud by using supercritical fluid extraction was compared with the essential oil obtained by steam distillation and microwave-assisted extraction by considering both quantity and quality of the product. The oil yield was higher in steam distillation and microwave oven extraction but oil extracted by using SFE contained higher amount of eugenol and eugenyl acetate.

Coriander (Coriandrum sativum L., family Umbelliferae) is a culinary and medicinal plant originating from the Mediterranean re- gion. The coriander seed contains essential oils, triglycerides, sugars, proteins and vitamin $\mathrm{C}$. By steam distillation only $0.5-2.0 \%(w / w)$ of essential oils can be recovered from the coriander seed. Coriander is widely used in folk medicine and the human diet featuring in the cuisines, as a seasoning agent in liqueurs, teas, meat products and pickles. Anitescu et al. [19] presented the results of steam distillation and $\mathrm{SC}-\mathrm{CO}_{2}$ extraction of ripe fruits of coriander. The SC- $\mathrm{CO}_{2}$ extraction was carried out in a two-stage separation system. The dynamic method at $323 \mathrm{~K}$ and $15 \mathrm{MPa}$ and an extraction period of 180 minutes at solvent flow rate of $3.0 \mathrm{l} / \mathrm{h}$ were used. The identification of 40 components was performed by GC/MS. The percentage composition of the identified compounds was compared with the composition of commercial coriander oil extracted by hydrodistillation. Illés et al. [20] studied the oil extraction from coriander seed with $\mathrm{CO}_{2}$ and propane as solvents, under sub- and supercritical conditions. The ratio of solvent to seed $(\mathrm{g}: \mathrm{g})$ required to achieve a complete oil extraction was between 298 and $313 \mathrm{~K}$ using $\mathrm{CO}_{2}$ at pressures of 20 and $30 \mathrm{MPa}$, and temperatures of 298 and $308 \mathrm{~K}$. The extract consists of, besides essential oils, triglycerides (glycerol triesters of fatty acids) and waxes. The changes in the tocopherol content of the extracts as a function of supercritical fluid extraction conditions were also investigated. Grosso [21] investigated supercritical $\mathrm{CO}_{2}$ fluid extraction of the volatile oil from Italian coriander seeds out under different conditions of temperature (313 and 323 $\mathrm{K})$, pressure $(9,10$ and $15 \mathrm{MPa})$, mean particle size $(0.4,0.6$ and $0.8 \mathrm{~mm})$ and $\mathrm{CO}_{2}$ flow rate $(0.79,1.10$ and $1.56 \mathrm{~kg} / \mathrm{h})$ in order to evaluate their influence on the yield and composition of the volatile oil. Hydrodistillation with the same mean particle sizes was performed and used as a comparative method. The best supercritical fluid extraction conditions were found to be 9 $\mathrm{MPa}, 313 \mathrm{~K}, 1.10 \mathrm{~kg} / \mathrm{h}$ and $0.6 \mathrm{~mm}$. The chemical composition of each supercritical fluid extraction sample was analyzed by GC and GCMS and the global composition was compared 
with that obtained by hydrodistillation. The dominant components were linalool (65-79 $\%), \gamma$-terpinene $(4-7 \%)$, camphor $(3 \%)$, geranyl acetate $(2-4 \%), \alpha$-pinene $(1-3 \%)$, geraniol (1-3\%) and limonene (1-2\%). Moreover, SFE samples were collected at specific intervals of amount of $\mathrm{CO}_{2}$ consumed, during each extraction, and the contribution of the main volatile components from each sample, for the global volatile compositions, was evaluated. In general, the first sample of each extraction contained up to $50 \%$ of the mass of each component. Yepez et al. [22] obtained fractions from seeds of coriander (Coriandrum sativum) by extraction with $\mathrm{SC}-\mathrm{CO}_{2}$ in a semicontinuous lab-scale equipment, and were tested for their antioxidant activity. Initially, the essential oil was removed from the herbal material by extraction with low density $(0.60 \mathrm{~g} / \mathrm{ml}) \mathrm{CO}_{2}$. Then the seeds were further extracted with high density $(0.73-0.83 \mathrm{~g} / \mathrm{ml}) \mathrm{CO}_{2}$ at pressures from 11.6 to $28 \mathrm{MPa}$ and temperatures from 311 to $331 \mathrm{~K}$. The antioxidant activity of the fractions was determined by measuring their ability to remove the free radicals present in a methanol solution of 1,1-diphenyl-2-picrylhydrazyl (DPPH). The extracts exhibited a significant activity, comparable to that of commercial antioxidants. These results indicate that SFE is a promising processing alternative for producing odorless and tasteless antioxidant fractions from coriander seeds.

Daphne tree (Laurus nobilis L.) is an evergreen that belongs to the Lauraceae family. Daphne trees grow wild in the coastal areas of the Mediterranean and Black Sea. Beis and Dunford [23] examined the $\mathrm{SC}-\mathrm{CO}_{2}$ extraction of oil from daphne seeds at pressure (14-28 $\mathrm{MPa})$, temperature (308-319.7 K), mean diameter of ground materials $(0.17-1.12 \mathrm{~mm})$, and solvent flow rate of $0.09 \square 10^{-3} \mathrm{~m}^{3} / \mathrm{h}$. The oil yield of ground seeds varied from 14 to $28 \%$ depending on the method and particle size used for oil recovery. Pressure had a significant effect on the extraction yield, so that the amount of extract collected increased with increasing pressure. The maximal extract yield was $26.95 \%(\mathrm{w} / \mathrm{w})$ at $68 \mathrm{MPa}$ and $348 \mathrm{~K}$. The extraction yield decreased significantly with increasing particle size. The composition of $\mathrm{SC}-\mathrm{CO}_{2}$ oil consists mostly of the following acids: lauric (43.1\% $\mathrm{w} / \mathrm{w})$, oleic $(37.2 \% \mathrm{w} / \mathrm{w})$, linoleic $(14.7 \% \mathrm{w} / \mathrm{w})$, palmitic $(4.9 \% \mathrm{w} / \mathrm{w})$, and myristic $(0.1 \% \mathrm{w} / \mathrm{w})$. The $\mathrm{SC}-\mathrm{CO}_{2}$ extraction was a viable technique to obtain high-purity Laurus nobilis L. seed oil. Isolation of volatile and fixed oils from dried berries of Laurus nobilis L. from Tunisia have been obtained by supercritical fractioned extraction with carbon dioxide [24]. Extraction experiments were carried out at a temperature of $313 \mathrm{~K}$ and pressures of 9 and $25 \mathrm{MPa}$. The extraction step performed at $9 \mathrm{MPa}$ produced a volatile fraction mainly composed of $(E)-\beta$ ocimene $(20.9 \%), 1,8$-cineole $(8.8 \%), \alpha$-pinene $(8.0 \%), \beta$-longipinene $(7.1 \%)$, linalool acetate $(4.5 \%)$, cadinene $(4.7 \%), \beta$-pinene $(4.2 \%)$, $\alpha$-terpinyl acetate $(3.8 \%)$ and $\alpha$-bulnesene $(3.5 \%)$. The oil yield in this step of the process was $0.9 \%$ by weight charged. The last extraction step at $25 \mathrm{MPa}$ produced an odorless liquid fraction, in which a very small percentage of fragrance compounds was found, whereas triacylglycerols were dominant. The yield of this step was $15.0 \%$ by weight. The most represented fatty acids of the whole berry fixed oil were 12:0 (27.6\%), 18:1 n-9 (27.1\%), 18:2 n-6 $(21.4 \%)$, and $16: 0(17,1 \%)$, with the $18: 1 n-9$ and 18:2 n-6 unsaturated fatty acids in particular averaging $329 \mu \mathrm{g} / \mathrm{mg}$ of oil.

Fennel (Foeniculum vulgare Mill.) is a plant of the family of Apiaceae (Umbelliferae). It is an anual, biennial, or perennial aromatic herb, depending on the variety, native of the Mediterranean region and it is cultivated in England, Germany, China, Vietnam and South America. The leaves, stalks, and fruits of the plant are edible. The essential oil of the most important fennel variety (var. dulce) contains monoterpenes, sesquiterpenes and other hydrocarbons. The essential oil or oleoresins from fennel are important ingredients for flavoring cosmetics, pharmaceuticals and food products. Simándi et al. [25] extracted a ground fennel seeds at laboratory scale $(P=8.2-8.4 \mathrm{MPa} ; T=$ 
304-308 K) with supercritical $\mathrm{CO}_{2}$ at a solvent flow rate of $0.12 \times 10^{-3} \mathrm{~m}^{3} / \mathrm{h}$ under varying extraction conditions in order to determine yield, composition and organoleptic characteristics of extract. SC-CO $\mathrm{CO}_{2}$ extraction of fennel seeds resulted in higher yield $(10 \%)$ than steam distillation $(3.0 \% \mathrm{w} / \mathrm{w})$. Pilot-scale preliminary extractions were also carried out at $30 \mathrm{MPa}$, and temperature $313 \mathrm{~K}$. Damjanović et al. [26] compared the $\mathrm{SC}-\mathrm{CO}_{2}$ extracts to fennel seed oil isolated by hydrodistillation. In the $\mathrm{SC}-\mathrm{CO}_{2}$ extraction, extracts as well in the hydrodistilled oil, the major compounds were trans-anethole, methylchavicol, and fenchone. It was found experimentally that, for the selected herb material, the optimal conditions of $\mathrm{SC}-\mathrm{CO}_{2}$ extraction were: pressure $10 \mathrm{MPa}$; temperature $313 \mathrm{~K}$, and extraction time $120 \mathrm{~min}$. Organoleptic tests confirmed that hydrodistilled oil possessed a less intense fennel seed aroma than extracts obtained by $\mathrm{SC}-\mathrm{CO}_{2}$ extraction. Reverchon et al. [27] presented the results of the $\mathrm{SC}-\mathrm{CO}_{2}$ extraction of fennel seeds which has been performed in two steps: the first step (9 MPa and $323 \mathrm{~K}$ ) to obtain the selective extraction of essential oil, and the second (20 MPa and $313 \mathrm{~K}$ ) which allows the extraction of vegetable oil. The experiments were performed using the fractional separation of the extracts using three different $\mathrm{CO}_{2}$ flow rates $(0.5,1.0$, and $1.5 \mathrm{~kg} / \mathrm{h})$. Yamini et al. [28] obtained essential oil of fennel cultivated in Iran by hydrodistillation and $\mathrm{SC}-\mathrm{CO}_{2}$ methods. The oils were analyzed by capillary gas chromatography using flame ionization and mass spectrometric detection. The compounds were identified according to their retention indices and mass spectra (EI, $70 \mathrm{eV}$ ). The effects of different parameters, such as pressure, temperature, modifier volume and extraction time, on the SFE of fennel oil were investigated. The results showed that, under pressure of 36.14 Mpa, temperature $328 \mathrm{~K}$, methanol $5 \%$ and dynamic extraction time of $45 \mathrm{~min}$, extraction was more selective for the extraction of $(E)$-anethol. Sixteen compounds were identified in the hydrodistilled oil. However, by using supercritical carbon dioxide in optimum conditions, only nine components represented more than $99 \%$ of the oil. The results showed that, in Iranian fennel oil, $(E)$-anethol is a major component.

Ginger (Zingiber officinale Roscoe) is a plant that belongs to the Zingiberaceae family. It is indigenous to the Asia Southeast. Ginger products, such as essential oil and oleoresin, are internationally commercialized for use in food and pharmaceutical processing. The essential oil, which is a mixture of monoterpenic and sesquiterpenic compounds, contains the volatile compounds responsible for the characteristic ginger flavor. The oleoresin contains the volatile oil and substances responsible for the pungent flavor of fresh ginger. Zancan et al. [32] examined the effects of temperature, pressure and the addition of co-solvent [ethanol (EtOH) and isopropyl alcohol (IsoC3)], both at $1.17 \%(w / w)$ on the kinetics of extraction of ginger oleoresin were studied. The experiments were achieved at pressures of 20 and $25 \mathrm{MPa}$; temperatures of 298 and $308 \mathrm{~K}$; solvent free $\left(\mathrm{CO}_{2}\right)$ flow rate of $0.2124-0.21672 \mathrm{~kg} / \mathrm{h}$, solvent $\left(\mathrm{CO}_{2}+\mathrm{EtOH}\right)$ flow rate of $0.2070-0.2168 \mathrm{~kg} / \mathrm{h}$, and solvent $\left(\mathrm{CO}_{2}+\mathrm{IsoC} 3\right)$ flow rate of 0.2034 $0.21456 \mathrm{~kg} / \mathrm{h}$. The identification of the substances present in the oleoresin was performed by GC/MS; GC/FID was used to determine the ginger extract compositions. The results show that the temperature and the interaction of the pressure and the solvent significantly affected the extraction yield. Martínez et al. [33] was studied the kinetics of SFE from vegetable raw materials in fixed beds. The operational conditions used in the extraction of ginger oleoresin were pressures of 15,20 , and $25 \mathrm{MPa}$, temperatures of 293, 303, and $313 \mathrm{~K}$, and a solvent flow rate of $5.6 \cdot 10^{-5} \mathrm{~kg} / \mathrm{s}$ of $\mathrm{CO}_{2}$. A mathematical model obtained from the differential mass balance in the extraction bed was presented. This model considers the extract as a mixture of various groups of compounds, classified according to their chemical characteristics. The interfacial mass flux of each group of compounds was assumed to be described by one of the solutions of the logistic equation. The model was able to describe quite well the experimental results 
for ginger oleoresin extraction, considering the extract either as a single pseudocompound or as the sum of three groups of compounds. The overall extraction curves were fitted by both the proposed model and Sovova's model; the sum of square deviations was lower for the proposed model.

Hyssop (Hyssopus officinalis), which is one of the most important pharmaceutical herbs, is extensively cultivated in central and south European countries such as Russia, Spain, France and Italy. Despite having a bitter taste, hyssop is used as a food flavor and also in sauce formulations and as a food ingredient. Kerolla et al. [29] investigated the separation of the four phenotypes of hyssop (blue, red, white, and mixed) by Soxhlet method using pentane/diethyl ether as a solvents, and by $\mathrm{SC}-\mathrm{CO}_{2}$ extraction at presssure of $10 \mathrm{MPa}$ and temperature of $313 \mathrm{~K}$. The supercritical extract contained a lower amount of monoterpene hydrocarbons and a higher amount of oxygenated hydrocarbons than the solvent extract. The intensity of odor of the phenotypes and their respective $\mathrm{CO}_{2}$ extracts was evaluated by sensory methods. The differences among the four phenotypes of hyssop were assessed by comparing the relative proportions of the 43 compounds, which were identified on the basis of their mass spectral data and retention indices. Kazazi et al. [30] studied $\mathrm{SC}-\mathrm{CO}_{2}$ extraction of hyssop at five various pressures in the intervals from 10.13 to $35.46 \mathrm{MPa}$, five different temperatures in the interval from 308 to $348 \mathrm{~K}$, extraction (dynamic and static) times and five different entrainer (methanol) concentrations in the interval from 0.0 to $6.0 \%(w / w)$. Results showed that increasing pressure from 10.13 to 30.975 $\mathrm{MPa}$ enhanced the extraction yield, which was due to the increased SC- $\mathrm{CO}_{2}$ density at higher pressures. Above $30.975 \mathrm{MPa}$, however, an increase in the pressure level led to a slight reduction in the extraction efficiency, which can probably be related to the reduced diffusion rates of the extracted materials from the sample matrix to the supercritical fluid environment. The composition of the extracted oils was greatly impacted by the operating conditions. A drop in the extraction yield was observed once a small amount $(1.5 \% \mathrm{w} / \mathrm{w})$ of the modifier was added into the system. Thereafter, the extraction yield was slowly improved with the addition of the modifier up to the $6.0 \%(w / w)$ level of this study. Langa et al. [31] studied the evolution of hyssop oil composition along the $\mathrm{CO}_{2}$ supercritical extraction curve, under changing extraction conditions, and compared the global composition of the extracts obtained to those from the more usual technique of hydrodistillation. In order to achieve this purpose, the effect on the oil yield and composition of two pairs of pressure and temperature values ( 9 $\mathrm{MPa}, 313 \mathrm{~K} ; 10 \mathrm{MPa}, 323 \mathrm{~K}$ ), three flow rates $(1.32,1.02,0.72 \mathrm{~kg} / \mathrm{h})$, and three particle sizes of vegetable material $(0.8,0.5,0.3 \mathrm{~mm})$ were studied. GC-MS analysis of the oil extracted at different time intervals is investigated. The hydrodistillation of the same vegetable material is also derived to compare both yield and composition with those from $\mathrm{SC}-\mathrm{CO}_{2}$ extraction. The higher yield was achieved with $9 \mathrm{MPa}$, $313 \mathrm{~K}$.

Juniper (Juniperus communis L., family Cupressaceae) is a native evergreen shrub/tree of regions in the Northern hemisphere with a substantial list of traditional uses owing to its medicinal properties and highly specific flavor, primarily associated with its volatile oil components. The essential oil is obtained mainly from the berries, mature female cones (Juniperi fructus), needles and their branches (Juniper foliage). The berries contain $0.2-3.42 \%(w / w)$ of volatile oil. The supercritical extraction with $\mathrm{CO}_{2}$ of ground fruits of the common juniper was extensivelly investigated in our laboratory [34-39]. The $\mathrm{SC}-\mathrm{CO}_{2}$ extraction was carried out at pressures $(8,9,10,15,20 \mathrm{MPa})$, temperature of $313 \mathrm{~K}$, with a particle size range from 0.25 to $0.40 \mathrm{~mm}$, and at a constant solvent flow rate of $0.2 \mathrm{~kg} / \mathrm{h}$. The total amount of extractable substances or maximum value of yield for the SFE process varied from 0.65 to $4.0 \%(w / w)$. At each investigated pressure, $\mathrm{SC}-\mathrm{CO}_{2}$ extract fractions collected in successive time intervals over the course of the extraction were analyzed by cap- 
illary gas chromatography, using flame ionization (GC-FID) and GC-MS. More than 200 constituents were detected in the extracts, and the contents of 50 compounds were reported by Barjaktarović et al. [37]. Dependence of the percentage yields of monoterpene, sesquiterpene, oxygenated monoterpene, and oxygenated sesquiterpene hydrocarbon groups on the extraction time was investigated, and conditions that favored the yielding of each terpene groups were emphasized. Nikolovski [38] found that increasing of the pressure caused the increase of the extract yield in $\mathrm{SC}-\mathrm{CO}_{2}$ extraction of juniper berries, at constant specific solvent flow rate (mass of $\mathrm{CO}_{2} /$ mass of raw material) and temperature of $313 \mathrm{~K}$ (Figure 3 ).

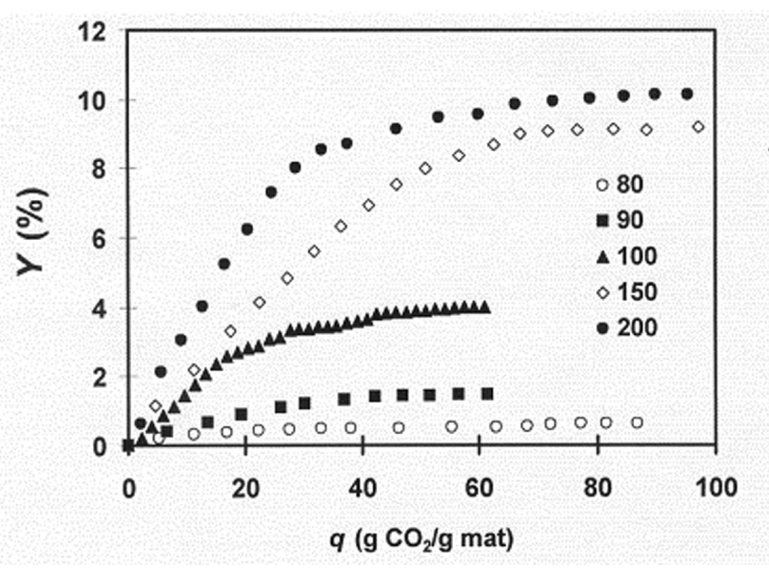

Fig. 3. Effect of pressure in the extraction of Juniperus communis on the extraction yield $(Y)$ versus the specific amount of solvent $(q)$ at $313 \mathrm{~K}$.

( $88 \mathrm{MPa}$; $9 \mathrm{MPa} ; \boldsymbol{\Delta} 10 \mathrm{MPa} ; \diamond 15 \mathrm{MPa}$; $20 \mathrm{MPa}$ ). [Source: Nikolovski, Ph.D. Thesis, University of Novi Sad, Novi Sad, 2009].

Isolation of essential oil from dried leaves, berries and wood of Juniperus communis L. ssp. nana were obtained with two different methods: by means of the classical hydrodistillation (HD) and by using carbon dioxide in the supercritical state (SFE). Operative conditions adopted in SFE were: pressure $9 \mathrm{MPa}$; temperature $323 \mathrm{~K}$. The leaf essential oil was made up of limonene (36.2\%), $\beta$-selinene (15.2 $\%)$ and $\alpha$-terpinyl acetate $(5.3 \%)$. The berry oil was composed chiefly of: limonene (40.1\%), germacrene D $(17.2 \%)$ and $\alpha$-pinene $(4.7 \%)$. The oil derived from the wood mainly consist- ed of: limonene $(8.9 \%), \alpha$-terpinyl acetate $(9.7$ $\%)$, and germacrene $\mathrm{D}(8.6 \%)$. The yields $(w / w)$ were $0.78 \%, 0.70 \%$ and $0.12 \%$ for leaves, berries and wood, respectively. The essential oil obtained by hydrodistillation did not differ significantly in composition but their yields were lower than those mentioned above. On the matrices exhausted owing to a SFE at $9 \mathrm{MPa}$, two further extractions at $323 \mathrm{~K}$ and at higher pressure $(20$ and $30 \mathrm{MPa})$ were performed in succession in order to obtain a mixture of compounds with higher molecular weight, Marongiu et al. [39]. The extract obtained at $20 \mathrm{MPa}$ on a charge of leaves inhibited the proliferation of cell derived from haematological and solid human tumours. Juniper berries were extracted by varying $\mathrm{CO}_{2}$ pressure from $9 \mathrm{MPa}$ to $20 \mathrm{MPa}$ at temperature of $313 \mathrm{~K}$, and the obtained extracts were compared with hydrodistilled essential oil [40]. The yield of juniper berry essential oil was much higher when the ground herb material was used, because the pre-treatment increases the surface area disrupting the cell walls, thus reducing the mass transfer resistance and making the essential oil more accessible to the steam. It was found that $\mathrm{SC}-\mathrm{CO}_{2}$ extracts generally contain higher percentages of oxygenated compounds, which strongly contributes to the fragrance. Therefore, the $\mathrm{SC}-\mathrm{CO}_{2}$ extraction gives better reproduction of the natural aroma of the juniper berries than hydrodistillation. During the $\mathrm{SC}-\mathrm{CO}_{2}$ extraction higher molecular weight compounds were extracted from herb material, but it was possible to modulate the extract composition by changing operation parameters. The present study shows that the supercritical carbon dioxide extraction of common juniper berries performed at the operating conditions 9 $\mathrm{MPa}$ and $313 \mathrm{~K}\left(\mathrm{CO}_{2}\right.$ density, $\rho\left(\mathrm{CO}_{2}\right)=0.485 \mathrm{~g} /$ $\mathrm{cm}^{3}$ ) minimizes the co-extraction of unwanted compounds and increases the yield of the flavour fraction.

Lavender flowers (Lavandula angustifolia) are aromatic plants with three main species (true lavender, spike lavender, and lavandin) and numerous subspecies. Although the essential oils of the true lavender, lavandin, and their 
subspecies contain up to $65 \%(w / w)$ linalool and linalyl acetate, which are used widely in perfumery, the essential oil of the spike species contains over $70 \%(w / w)$ camphor and fenchone, which are used as pharmaceutical products. True lavender essential oil was extracted using supercritical $\mathrm{CO}_{2}$ as the solvent, and the chromatographic analysis of the oil extracted was studied by Reverchon et al. [41]. The SC$\mathrm{CO}_{2}$ extraction was carried out in the pressure range from 8 to $12 \mathrm{MPa}$ and for temperatures between 308 and $333 \mathrm{~K}$. Fractional separation of the extracts was also performed with the scope of selectively precipitating cuticular waxes. The major difference between lavender oil produced by supercritical extraction and by hydrodistillation was reflected in the linalyl acetate content. Da Porto et al. [42] identified sixty compounds of Lavandula angustifolia L. and quantified them by GC-MS and GC-FID from extracts obtained by means of hydrodistillation, supercritical $\mathrm{CO}_{2}$ extraction and ultrasound-assisted extraction. The best extracts, in terms of amount of isolated compounds, flavour quality and stability were those obtained with $\mathrm{SC}-\mathrm{CO}_{2}$ extraction. Agkün et al. [43] extracted the essential oil from lavender flowers (Lavandula Stoechas subspecies Cariensis Boiss) in a semicontinuous system by supercritical $\mathrm{CO}_{2}$. Experiments were carried out in the ranges of 8-14 MPa pressures, 328-333 K temperatures, and $0.06552-0.1310 \mathrm{~kg} / \mathrm{h}$ solvent flow rates. In these experiments was concluded that the extraction rate increases because of the increase in the solute solubility where the effect of the vapor pressure increase overcame the effect of the solvent density decrease. Because the essential oils have lower solubility in $\mathrm{CO}_{2}$ below the solute-solvent mixture "cross-over" pressure, which is about $9.6 \mathrm{MPa}$ at $323 \mathrm{~K}$, the extraction rate at $8 \mathrm{MPa}$ was lower than both of those at 12 and $14 \mathrm{MPa}$. At 12 and $14 \mathrm{MPa}$, however, the extraction rates were close to each other because of the miscibility of essential oil with the supercritical $\mathrm{CO}_{2}$. It means that the solubility is controlled by a balance between solvent density and solute vapor pressure changes.
Oregano (Origanum majorana L.) is labeled "sweet marjoram" or "knotted marjoram". The knotted marjoram label is applied because of the type of flowers, which are in small clusters or knot-like shapes before blossoming. Sweet marjoram is a tender perennial usually grown as an annual. Native to North Africa and South-west Asia, it is naturalized in the Mediterranean region and cultivated in North America. The fresh or dried highly aromatic leaves and flowering tops of marjoram (Majorana hortensis Moench.) are widely used to flavour many foods. Its essential oil and alcoholic extracts are applied in pharmaceuticals, perfumes and cosmetics. Volatile components of marjoram (Origanum majorana L.) essential oil obtained by hydrodistillation and extracts obtained by solvent extraction with ethyl alcohol and $\mathrm{SC}-\mathrm{CO}_{2}$ extraction were investigated by Vági et al. [44]. Rodriges et al. [45] obtained the extracts at pressure of $45 \mathrm{MPa}$, temperature of $323 \mathrm{~K}$, and solvent flow rate of $7.0 \mathrm{~kg} / \mathrm{h}$. The yield of $\mathrm{SC}-\mathrm{CO}_{2}$ extraction was $3.8 \%(w / w)$. Marjoram extracts obtained by supercritical $\mathrm{CO}_{2}$ extraction and alcoholic Soxhlet extraction have promising potentials for incorporation into various food, cosmetic and pharmaceutical products for which a natural aroma, colour, and antimicrobial additive is desired. In this work sub- and supercritical $\mathrm{CO}_{2}$ were used to obtain extracts from two origanum samples, one commercial, and another cultivated under agronomic control. The experiments were performed in the temperature range of $303-323 \mathrm{~K}$ and from 10 to $20 \mathrm{MPa}$ in pressure, employing around $26 \mathrm{~g}$ of origanum samples. Results show that the commercial sample provides a higher yield of extract if compared to the other sample. It is also achieved that a raise in temperature at constant pressure leads to an increase in the extraction yield despite solvent density changes. Chemical analyses were carried out in a GC-MS, allowing the identification of around 24 compounds by use of the library of spectra of the equipment and injection of some standard compounds for both commercial and cultivated origanum samples. It was also found that the distribution of chemical components as a function of extraction time differs appreciably between the 
origanum species. The chromatographic analysis permitted the identification of thymol and cis-sabinene hydrate as the most prominent compounds present in commercial oregano sample and carvacrol and $c i s$-sabinene hydrate in the cultivated Origanum vulgare. Vagy et al. [46] investigated the extraction of pigments (chlorophylls and carotenoids) from marjoram (Origanum majorana L.) with supercritical carbon dioxide. The aim of this study was to map the effects of extraction pressure and temperature on the yield of coloring materials by applying a 32 full factorial design with three repeated tests in the center of the design. For comparison, laboratory and pilot plant Soxhlet extractions were carried out using ethanol and $n$-hexane solvents. The compositions of pigments in marjoram extracts were determined by liquid chromatographic (HPLC). Similar amounts of carotenoids, in addition to $40 \%$ of chlorophylls and their derivatives, were recovered from the supercritical fluid extraction, in comparison to the ethanol Soxhlet extraction.

Pennyroyal (Mentha piperita L.) belongs to the Labiatae family, and has a significant content of essential oils, some of them being utilized in perfumery, or as spices in foods. It grows naturally now in the north of Iran, and in the Mediterranean area. The nutritional benefits of the essential oil are primarily related to the fatty acid composition, mainly due to the high content of oleic acid, and also to the balanced ratio of saturated and polyunsaturated fatty acids. Aromatic plants have also been used since ancient times, in food flavouring, pharmaceutical, cosmetic and perfumery due to the presence of essential oils. Aghel et al. [47] studied the extraction of Mentha pulegium L. (pennyroyal) essential oil by supercritical $\mathrm{CO}_{2}$ with the following process parameters: pressure (10.13-30.39 MPa), temperature (308-323 K), extraction time (dynamic), and modifier (methanol). The results were also compared with those obtained by conventional hydrodistillation method in laboratory conditions. The optimum SC$\mathrm{CO}_{2}$ conditions in regarding the percentages of menthone and pulegone were defined. Reis-Vasco et al. [48] investigated $\mathrm{SC}-\mathrm{CO}_{2}$ extraction of the flowers and leaves of pennyroyal (Mentha pulegi- um L.), followed by a two-stage fractional separation technique. The best conditions of extraction $(P=10 \mathrm{MPa}$ and $T=323 \mathrm{~K})$ were found and used to investigate the effect of different mean particle diameters. The pennyroyal oil obtained under these conditions was compared with that obtained by hydrodistillation.

Red pepper or paprika (Capsicum annuum L.) belongs to the Tubiflora order of the Solanaceae family. Paprika contains oily, aromatic, pungent and colour compounds. Paprika oleoresin is its lipidic extract, obtained as red sticky oil, with a characteristic red pepper flavor. The interest in paprika oleoresin is mainly due to its colorant power. This property has a number of applications in food, cosmetic, and pharmaceutical industries. Daood et al. [49] extracted pungent spice paprika powder to obtaine oleoresin with supercritical $\mathrm{CO}_{2}$ at 10-40 MPa pressure and 308-328 $\mathrm{K}$ temperature. The extraction yield increased with increasing the pressure at a given temperature, beacuse of increasing the oil solubility in SC- $\mathrm{CO}_{2}$. Except at $328 \mathrm{~K}$ and low pressures, the extraction conditions did not effect considerably the solubility of tocopherols in solvent used. The capsaicinoids were easily rebuilded with $\mathrm{SC}-\mathrm{CO}_{2}$. In addition to the oleoresin yield, quality and nutritional components such as carotenoids, tocopherols and capsaicinoids, the heat principles of paprika, were determined using HPLC methods. Uquiche et al. [50] investigated the supercritical extraction with $\mathrm{CO}_{2}$ of red pepper at pressure of 32,43 and $54 \mathrm{MPa}$, temperature of $313 \mathrm{~K}$, solvent superficial velocity of $2.052,3.312$, and $4.50 \mathrm{~m} / \mathrm{h}$, and diameter of grinding material of $0.273,0.689$, 2.92 , and $3.90 \mathrm{~mm}$. The yields of oleoresin and carotenoid pigments increased with an increase in pressure in the extractor. This meaning full effect of process pressure on extraction rate could be due to the increase in solubility of red pepper oleoresin in general, and carotenoid pigments in particular, as the solvent power of SC-CO increases. This increase in solubility would confessedly result in a larger driving force for mass transfer at high pressure (43-54 MPa) than lower pressure (32 MPa). It was also observed that as average diameter increases the extraction rate decreases. 
These results could be explained by an increase in the resistance to mass transfer due to an increase in the diffusion path within solid particles and a reduction in the area for mass transfer. Extraction curves for different values of superficial velocity were superimposed initially, which indicates that external mass transfer phenomena did not effect extraction rates. It is suggested that solute partition between the solid and SC- $\mathrm{CO}_{2}$ controls the initial stages of the extraction process, and the common initial slope of the plot defines the apparent solubility of red pepper oleoresin in $\mathrm{SC}-\mathrm{CO}_{2}$ at $313 \mathrm{~K}$ and $32 \mathrm{MPa}$.

Safflower (Carthamus tinctorius L.) is extensively cultivated in India, China, USA, Mexico, and Turkey. The safflower is an important kind of oil crop because of abundant oil $(27-32 \% \mathrm{w} / \mathrm{w})$ in the seeds and seed oil's richness 70-87\% $(w / w)$ in the linoleic acid. Moreover, safflower seed oil is also a rich source of vitamin E. Han et al. [51] extracted safflower seed oil with supercritical $\mathrm{CO}_{2}$ at series operational parameters of pressure $(22,25$, $28 \mathrm{MPa})$, temperature $(308,313,323,333 \mathrm{~K}$, flow rate $(0.98,1.31,1.49,3.74 \mathrm{~kg} / \mathrm{h})$, and particle size $(0.35,0.85 \mathrm{~mm})$ in a bench scale apparatus. The results show that the extraction rate increases significantly with the increase of pressure, due to the increase of the $\mathrm{SC}-\mathrm{CO}_{2}$ density, which results in the increase of its dissolving abillity and solubility of the oil compounds. Extraction rate and the total extraction yield at $308 \mathrm{~K}$ are slightly higher than those at higher temperatures. The solubility of oil directly effects the extraction rate and it is controlled by balance between the $\mathrm{SC}-\mathrm{CO}_{2}$ density and the oil vapor pressure. The independence of the extraction yield on the solvent flow rate indicates that process is controlled by solubility of the oil in the initial period. During the later period of extraction, the extraction process is mass transfer controlled and the extraction rate is low. The use of the smaller particles caused the greater the effective fluid-solid contact are, the higher the extraction rate. Additionally, the quality of safflower seed oil obtained by supercritical $\mathrm{CO}_{2}$ extraction is superior to that of oil obtained by traditional methods. It was shown (Figure 4) that the effect of $\mathrm{CO}_{2}$ flow rates on the extraction are differently.
It is noted that from 0 to $5 \mathrm{~kg}$ of $\mathrm{CO}_{2}$ used, all of experimental data fall on the same sloped straight lines. The independence upon the flow rate indicates that the process is controlled by the solubility of the oil in the initial period. From the slope of the straight part of the curves, we can obtain approximately the solubility of the oil contained in the safflower seeds, which yields nearly $4.9 \mathrm{~g}$ of oil $/ \mathrm{kg} \mathrm{CO}_{2}$ at $308 \mathrm{~K}$ and $28 \mathrm{MPa}$. From 5 to 7 $\mathrm{kg}$ of $\mathrm{CO}_{2}$ used, a decrease of extraction rate is observed. That is because the mass transfer rate of difficult accessible oil is significantly lower than that of easily accessible oil. During the latter period of extraction, the extraction is mass transfer controlled and the extraction rate is low. Han et al. [52] obtained safflower essential oil and carthamin from safflower dreg by supercritical $\mathrm{CO}_{2}$ two-step extraction, a series operational parameters of pressure, temperature and $\mathrm{CO}_{2}$ flow rate were investigated in a bench-scale apparatus. The result shows that the rise of $\mathrm{CO}_{2}$ flow rate and the decrease of temperature lead to the increase in extraction rate of safflower dreg. Furthermore, the optimum conditions of extraction of safflower dreg are: in the first-step extraction, temperature at $308 \mathrm{~K}$, pressure at $9 \mathrm{MPa}, \mathrm{CO}_{2}$ flow rate at 3.74 $\mathrm{kg} / \mathrm{h}$, in the second-step extraction, temperature at $308 \mathrm{~K}$, pressure at $30 \mathrm{MPa}$, and $\mathrm{CO}_{2}$ flow rate at $3.74 \mathrm{~kg} / \mathrm{h}$. The extraction rates of essential oil and carthamin are $2.74 \%$ and $69.88 \%$, respectively.

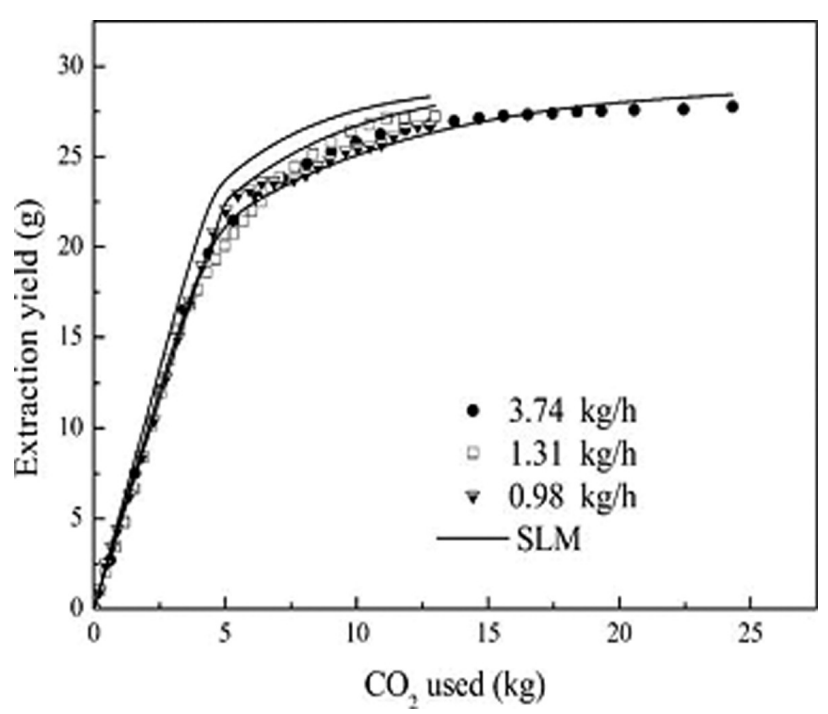

Fig. 4. Effect of flow rate on extraction of safflower at $T=308 \mathrm{~K} ; P=28 \mathrm{MPa}$, and particle size $0.35 \mathrm{~mm}$. [Source: Han et al., J. Food Eng., 92, 370-376 (2009)] 
Genus Salvia is one of the most widespread members of the Lamiaceae family. Many Salvia subspecies are used as herbal tea and for food flavouring as well as in the cosmetics, perfumery and pharmaceutical industries. Sage preserves a variety of foods, including meats and cheeses. Aleksovski and Sovová [53] extracted Dalmatian sage (Salvia officinalis L.) with sub- and supercritical $\mathrm{CO}_{2}$ at pressures of 9-12.8 MPa, temperatures 298-323 K and solvent flow rate in a range of $0.003-0.021$ $\mathrm{kg} / \mathrm{h}$. Initial essential oil content was $2.7 \%$ $(w / w)$, and the global extraction yield varied between 2.7 and $4.8 \%(w / w)$ in dependence on extraction conditions. In the initial period of the extraction process the essential oil was collected, which was liquid, homogeneous and similar to the essential oil extracted by hydrodistillation. After the short first period, the extraction rate decreased and the cuticular waxes and water that were co-extracted with essential oil appeared as a separate phase. Glišić et al. [54] investigated the supercritical carbon dioxide (SFE) extraction of Dalmatian sage (Salvia officinalis L.), was investigated and compared to extraction performed by Soxhlet ethanol-water (70:30) mixture extraction (SE) and hydrodistillation (HD). The supercritical extraction allowed isolation of wide spectrum of phytochemicals, while other applied methods were limited to either volatiles (HD) or high molecular compounds isolation (SE). The kinetics of the supercritical extraction and fractionation within the pressure range of $10-30 \mathrm{MPa}$ at 323 $\mathrm{K}$ were also analyzed as well as the chemical compositions of total extract and partial or differential fractions isolated at different $\mathrm{CO}_{2}$ consumption. Volatile fraction could be isolated at low pressure and low $\mathrm{CO}_{2}$ consumption, whereby the pressures between 10 and $15 \mathrm{MPa}$ followed by increased $\mathrm{CO}_{2}$ consumption were favourable for obtaining desired selectivity of diterpenes which contain compounds with expressed antioxidative characteristics.

Turmeric (Curcuma longa L.) is a common species among the aromatic plants in South America. The roots are used in dairy food as colorant and flavoring substitute for saffron. Turmeric contains curcuminoids that have antimutagenic and antioxidant activities, and is thus used for the formulation of foods for the prevention of cancer. Braga and Meireles [55] investigated the $\mathrm{SC}-\mathrm{CO}_{2}$ extraction of turmeric oil, using a mixture of $\mathrm{CO}_{2}$ and $\mathrm{EtOH} / \mathrm{IsoC} 3$, and used the traditional processes, such as hydrodistillation process, the Soxhlet extraction, because of the comparing the results. The $\mathrm{SC}-\mathrm{CO}_{2}$ experiments were performed in a fixed bed extractor at pressure of $30 \mathrm{MPa}$, temperature of $303 \mathrm{~K}$, and solvent flow rate of $0.211 \mathrm{~kg} / \mathrm{h}$. The bed's height in the extractor affect was studied, maintaining constant the bed diameter and porosity; for the accelerated solvent extraction, the co-solvent percentages used were 10,50 and $90 \%(w / w)$, with or without a static period of $30 \mathrm{~min}$. The overall extraction curves showed that by keeping the relation between solvent and raw material constant, maximum extraction yield was obtained in a shorter time using the lowest bed height $(\mathrm{HB} / \mathrm{DB}=1.8)$. The supercritical fluid extraction using $50 \%$ of the co-solvent that employed the static period increased the curcuminoid content and reached $10 \%$ of extract yield. The global extraction yield was higher at $20 \mathrm{MPa}$ when the EtOH/IsoC3 co-solvent mixture was used, while the smaller value was obtained when using of the EtOH. The presence of a co-solvent will contribute to a more complex behavior of the system. Thus, at $20 \mathrm{MPa}$, the interactions of the type solute $/ \mathrm{CO}_{2} / \mathrm{IsoC} 3$ were stronger than that of the type solute $/ \mathrm{CO}_{2} / \mathrm{EtOH}$ and predominated even for the co-solvent mixture $\mathrm{EtOH} /$ IsoC3. At $30 \mathrm{MPa}$, the interactions of the type solute $/ \mathrm{CO}_{2} / \mathrm{EtOH}$ are probably positively affected the global extraction yield and the curcuminoids content. This behavior indicates that the retrograde phenomenon was observed at the conditions used in this study. The solubility of a solute in a supercritical solvent and the global extraction yield are influenced by two phenomena: $(i)$ the solute vapor pressure, and (ii) the solvent density. The solvent flow rate did not affect the composition of the $\mathrm{SC}-\mathrm{CO}_{2}$ extracts. 
Gopalan et al. [56] extracted turmeric oil from turmeric (Curcuma longa) with supercritical carbon dioxide in a semicontinuous-flow extractor. Extraction rate was measured as a function of pressure, temperature, flow rate, and particle size. The extraction rate increased with an increase in $\mathrm{CO}_{2}$ flow rate and with a reduction of particle size. The effect of pressure and temperature on turmeric extraction suggested the use of higher pressure and lower temperature at which solvent density is greater and thus the solubility of the oil in the solvent is greater in the range of $313-333 \mathrm{~K}$ and $20-40 \mathrm{MPa}$. The major components $(\sim 60 \%)$ of the extracted oil were identified as turmerone and ar-turmerone by GC-MS.

Nguyen et al. [57] extracted oleoresin from vanilla beans with $2-62 \mathrm{~g} \mathrm{CO}_{2} / \mathrm{g}$ dried bean at 306-309 $\mathrm{K}$ and 10-13 MPa. Effects of extraction time (5 to $1540 \mathrm{~h}$ ), water-soaking of beans, and cryogrinding of beans on oleoresin yield and composition were determined. Vanillin yields up to $95 \%$ were obtained. Extraction rate was first-order with respect to unextracted oleoresin concentration. Vanillin purity was higher with supercritical $\mathrm{CO}_{2}$ extraction than with conventional aqueous ethanol extraction; the vanillin represents $74-97 \%$ of the flavor and fragrance compounds, measured by liquid chromatography, when using $\mathrm{CO}_{2}$ compared to $61 \%$ using alcohol extraction. Rodrigues et al. [58] concluded that coumarin is an active principle found in several vegetable species with a characteristic smell of vanilla. It is widely used as a perfume fixer, paint and spray additive, and in cleaning products. It also possesses clinical value due to antibiotic and analgesic properties, besides its potential use in the treatment of cancer and AIDS. The objective of this work was to obtain solubility data for coumarin under several conditions, as well as to evaluate process parameters for its extraction from emburana seeds with supercritical $\mathrm{CO}_{2}$. The process parameters studied were temperature, pressure, $\mathrm{CO}_{2}$ flow rate and particle size of the seeds. The solubility in supercritical $\mathrm{CO}_{2}$ was correlated using the Peng-Robinson equation. Solid-supercritical fluid and liquid-supercritical fluid equilibria were considered and correlated separately, with L-SC presenting better results due to the effect of the melting point depression of coumarin under high pressure. The results showed significant effects of pressure and temperature on the extraction yield and also, the smaller the particle size of the seeds, the better the yield.

Extraction rate/solubility of solutes can be increased with increasing extraction pressure, because of the solvent power increase. In all of the systems investigated, connected with the effect of the extraction pressure on the global extraction yield in $\mathrm{SC}-\mathrm{CO}_{2}$ extraction, it was shown that the extraction yield increases with increasing pressure, when the temperature, the solvent flow rate, and the diameter of the grinding material remain constant. The extraction rate was higher at higher pressure for most of the systems investigated. The reason for this is that at constant temperature, the density of the solvent increases with pressure increase and the vapor pressure of the solute decrease with pressure increase. However, the increase in solvent density with pressure overcomes the relatively small change of solute vapor pressure.

Concerning the extraction temperature, two effects on extraction rate/solubility of solutes can be observed: either a decrease or an increase with an increase in temperature depending on the extraction pressure. Namely, an increase in temperature results in the reduction in solvent density (lower extraction rates/solubility) and the increase of the solute vapor pressure (higher extraction rates/solubility). These two competing effects have the same effectiveness only at the "cross-over" pressure, when the temperature does not show any influence on extraction rates/solubility. At lower pressure, the change of solvent density is more effective than that of the solute vapor pressure, as extraction rate/solubility increases with a decrease in temperature. However, at a pressure higher than the "cross-over" pressure, the extraction rate is dependent on the solute vapor pressure and it increases with an increase in temperature. This 
is the temperature inversion. This phenomenon was recorded in the systems: black pepper oil$\mathrm{CO}_{2}[5]$, and lavender oil- $\mathrm{CO}_{2}[43]$.

The extraction rate can be increased by using smaller spice particle sizes, when diffusion process controls mass transfer rates, since specific interfacial area increases and the diffusion length shortens. Smaller particles, although better for mass transfer, decrease the fluidized bed velocity, can tend to channeling, and can cause clogging of filters. A further possibility for increasing extraction yield is to employ higher solvent flow rates. Mass transfer coefficients increase with an increase in Reynolds number, and higher flow rates give a larger mean concentration gradient because the loading of the extraction solvent with a solute is lower, and a better mixing effects the extractor. In some of the systems investigated (black pepper oil- $\mathrm{CO}_{2}$ [4]) it was shown that the increase of the flow rate benefited the extraction rate. On the contrary, Papamichail et al. [10] concluded that the yield decreased with increases of the flow rate of the solvent, system: celery seed oil- $\mathrm{CO}_{2}$.

The effects of the extraction kinetics and the co-solvent amount on the composition of the $\mathrm{SC}-\mathrm{CO}_{2}$ extracts are presented in some of the presented papers. As expected, the solvent flow rate did not affect the composition of the $\mathrm{SC}-\mathrm{CO}_{2}$ extracts. Experimental data presented for the system turmeric oil- $\mathrm{CO}_{2}[55]$ show that the amount of co-solvent (IsoC3 or EtOH) as well as solvent affected appreciably the yields and the content of curcuminoids content, but the same trend was not observed for the light fraction in the $\mathrm{SC}-\mathrm{CO}_{2}$ extracts (the fraction that contains the compounds quantified by GCFID).

The global SC-CO $\mathrm{C}_{2}$ extraction yield was mostly compared with the hydrodistillation yield, traditional Soxhlet extraction yield, and organic extracts one. The composition of the extracts was analyzed by GC-FID and GC-MS in all the systems investigated.

\section{MATHEMATICAL MODELLING}

The study of supercritical extraction curves and the knowledge of the effects of the operational variables allow the definition of the extractor volume and solvent flow rate. The mathematical model of vegetable oil extraction with $\mathrm{SC}-\mathrm{CO}_{2}$, widely used in the literature, was introduced by Sovová [59], who extended Lack's plug flow model. The Sovová's model is based on the following assumptions [59]:

- Temperature and pressure are constant during extraction;

- Solid bed is homogeneous with respect to particle size and initial distribution of the oil;

- Bed porosity is not affected by the reduction of the oil during extraction;

- $\mathrm{SC}-\mathrm{CO}_{2}$ is oil-free at the extractor entrance;

- Mass transfer phenomena of all extract are similar.

In this model the extraction process is divided into three periods. The first period corresponds the constant extraction rate, which can be determined by the oil's solubility in $\mathrm{SC}-\mathrm{CO}_{2}$. During the second transition period, the particles at the bed entrance will first lose all the easily accessible oil that they initially contained, but the particles at the bed outlet still have lots of easily accessible oil. The extraction rate falls rapidly during this period. The extraction rate becomes very slow in the last period, because all easily accessible oil has been extracted by $\mathrm{SC}-\mathrm{CO}_{2}$. Plug flow of supercritical solvent through a fixed bed of milled material was considered. The basic assumption of the model is that a part of the cells (the hypothetical oil-containing units) was opened by milling. Sovová's mass transfer model (STM) takes into account the solute solubility in the solvent phase and the mass transfer coefficient both in the fluid and in the solid phases, neglecting the accumulation of the solute in the fluid phase. The model assumes pseudo-steady state and plug flow, with temperature, pressure, and solvent velocity being kept constant throughout the operation. The model 
also assumes that the bed is homogeneous regarding the particle size distribution and the initial solute distribution in the bed. Axial dispersion and solute accumulation in the fluid phase are assumed to be negligible. Sovová's model has proved to describe very well the supercritical fluid extraction of several products presented in the literature, such as grape oil [60], black pepper [4, 8, 61], aniseed oil [62] and apricot kernel oil [63]. Sovová's mathematical model gave the best results in the $\mathrm{SC}-\mathrm{CO}_{2}$ extraction some of the selected spice oil presented in this paper, such as black pepper oil [61], ginger oil [32], hyssop oil [30], and safflower oil [52]. The total of mass transfer driving force and the equilibrium absorption constant were fitted by the linear driving force approximate theory, and simulation results agreed pretty weel with the experimental ones in the system black pepper oil- $\mathrm{CO}_{2}$ [5]. Hong et al. [64] developed a mathematical model which was used to the calculation of the theoretical extraction curve. These authors divided a single extraction curve into two sections: the constant extraction rate followed by the falling extraction rate. It is assunmed that the region of constant extraction rate follows a film-controlling mass transfer mode and that the region of falling extraction rate follows a diffusion-controlling mass transfer rate. This model was successfully applied to the supercritical extraction of some of the spice materials, presented in this paper, such as juniperus communis oil [38]. The model which contained only one adjustable parameter (effective diffusivity, De) was using for the correlation of experimental data in the system lavender oil- $\mathrm{CO}_{2}$ [30]. Two mathematical models were constructed, based on the numerical integration of differential mass balances written along the extraction bed in the system pennyroyal essential oil- $\mathrm{CO}_{2}$ [48]. Axial dispersion was also taken into account. On the basis of the extraction results and of the analysis of scanning electron microscopy (SEM) images of the vegetable matter, mathematical models of the two extraction processes have been proposed. Reverchon et al. [27] proposed a model which was based on the integration of differential mass balances performed along the extraction bed. The model was based on the hypothesis that the external mass transfer resistance was negligible. Moreover, it supposed that the extraction was uniform along the bed and that variations of solute concentration in the fluid phase (lavender oil$\mathrm{CO}_{2}$ ) were negligible. The extraction of fennel vegetable oil has been modeled using a model based on differential mass balances and on the concept of broken and intact cells as evidenced by scanning electron microscopy (SEM) [18]. A mathematical model obtained from the differential mass balance in the extraction bed, for the case of $\mathrm{SC}-\mathrm{CO}_{2}$ extraction of ginger oleoresin, was presented [32]. This model considers the extract as a mixture of various groups of compounds, classified according to their chemical characteristics. The interfacial mass flux of each group of compounds was assumed to be described by one of the solutions of the logistic equation. The model was able to describe quite well the experimental results for ginger oleoresin extraction, considering the extract either as a single pseudocompound or as the sum of three groups of compounds. The overall extraction curves were fitted by both the proposed model and Sovová's model; the sum of square deviations was lower for the proposed model [20]. In the $\mathrm{SC}-\mathrm{CO}_{2}$ extraction of lavender flower the extraction process was modeled by a quasi-steady-state model as function of extraction time, flow rate, pressure, and temperature [42]. In the supercritical extraction of pungent spice paprika the authors estimated Chrastil equation [65] constants/adjustable parameters [49] for paprika oil equilibrium solubility isotherms. Žižović et al. [66] presented a mathematical model which includes the phenomenon of peltate gland disruption simulutes the process of Lamiaceae family species supercritical fluid extraction with high accuracy $(0.83 \%)$. This model indicated the possibility of the supercritical fluid extraction optimization towards lowering of the $\mathrm{SC}-\mathrm{CO}_{2}$ consumption. The optimal supercritical fluid extraction processing should include a grinding followed 
by $\mathrm{SC}-\mathrm{CO}_{2}$ batch (nonflow) pre-tretment prior to continuous flow extraction. The model was applied to simulate basil, rosemary, marjoram and pennyroyal $\mathrm{SC}-\mathrm{CO}_{2}$ extraction on the existing experimental data [66].

\section{CONCLUSIONS}

This article deals with supercritical fluid extraction (SCE) of some of the spice plant materials by carbon dioxide as a solvent. The extracts as products can be used in the food, perfume and cosmetic industry, as well as a ingredients in culinary recipes. The process parameters of SCE extraction: pressure, temperature, flow of the solvent, diameter of the grinding material, and volume ratio of cosolvents were investigated. The results of SCE extraction for the spice plant materials: black pepper, caraway, clove, coriander, daphne, fennel, ginger, hyssop, juniper, lavender, marjoram, oregano, pennyroyal, red pepper, safflower, sage, and turmeric were presented. The data of global yield of extraction for the most of spice plant materials as a function on process parameters were given. It was noted that the maximum value of extraction yield $(56.0 \% \mathrm{w} / \mathrm{w})$ gave the extraction of red pepper, but the minimum value of extraction yield gave the extraction of cinnamon $(0.78 \%$ $w / w)$. The composition of $\mathrm{SC}-\mathrm{CO}_{2}$ extracts for all the investigated spice plant materials was very complex, and in the any case the extracts have a more than 200 components. In most of the systems investigated the supercritical extraction exhibited superior advantages over steam distillaton or solvent extraction, mainly due to the fact that the obtained extracts were with concentrated active components, and the products were without residues of undesirable solvents. In all of the systems investigated, it was shown that the extraction yield increases with increasing pressure, when the temperature, the solvent flow rate, and the diameter of the grinding material remain constant. The extraction rate was higher at higher pressure for most of the systems investigated. Concerning the ex- traction temperature, two effects on extraction rate/solubility of solutes can be observed: either a decrease or an increase with an increase in temperature depending on the extraction pressure. Namely, an increase in temperature results in the reduction in solvent density (lower extraction rates/solubility) and the increase of the solute vapor pressure (higher extraction rates/ solubility). These two competing effects have the same effectiveness only at the "cross-over" pressure, when the temperature does not show any influence on extraction rates/solubility. As can be expected, the extraction rate can be increased by using smaller spice particle sizes, when diffusion process controls the mass transfer rates, since specific interfacial area increases and the diffusion length shortens. Smaller particles, although better for mass transfer, decrease the fluidized bed velocity, can tend to channeling, and can cause clogging of filters. Mass transfer coefficients increase with an increase in Reynolds number, and higher flow rates give a larger mean concentration gradient because the loading of the extraction solvent with a solute is lower, and a better mixing effects the extractor. In some of the systems investigated was shown that the increase of the flow rate benefited the extraction rate. On the contrary, some of the authors concluded that the yield decreased with increases of the flow rate of the solvent, system.

In some of the essential oil- $\mathrm{CO}_{2}$ systems investigated in this paper the different mathematical models (Sovová, Hong), which have been taken from the literature, were used to correlate the experimental data.

Acknowledgment: This research was supported by the Ministry for Science and Technological Development of the Republic of Serbia (Project No. 20022).

\section{REFERENCES}

[1] M.A. McHugh, V.J. Krukonis, Supercritcal fluid extraction - Principles and Practice, Butterworth Publishers, Boston, 1986. 
[2] M. Mukhopadhyay, Natural extracts using supercritical carbon dioxide, CRC Press., Boca Raton, London, New York, Washington, D. C., 2001.

[3] S.R.S. Ferreira, Ž.L. Nikolov, L.K. Doraiswamy, M.A.A. Meireles, A.J. Petenate, Supercritical fluid extraction of black pepper (Piper nigrum L.) essential oil, J. Supercrit. Fluids. 14, 235-245 (1999).

[4] C. Perakis, V. Louli, K. Magoulas, Supercritical fluid extraction of black pepper oil, J. Food Eng. 71, 386-393 (2005).

[5] Zh. Li., X. Lu, Sh. Chen, X. Zhang, X. Yuanjing, Y. Wei, Y., F. Xia, An experimental and simulating study of supercritical $\mathrm{CO}_{2}$ extraction for pepper oil, Chem. Eng. Process. 45, 264-267 (2006).

[6] K. Bauer, D. Garbe, Common fragrance and flavor materials. Preparation, properties and uses, VCH Publishers, Weinheim, Germany, 1985.

[7] T. Baysal, D.A., J. Starmans, Supercritical carbon dioxide extraction of carvone and limonene from caraway seed, J. Supercrit. Fluids. 14, 225-234 (1999).

[8] H. Sovová, R. Komers, J. Kučera, J. Jež, Supercritical carbon dioxide extraction of caraway essential oil, Chem. Eng. Sci. 49, 2499-2505 (1994).

[9] M. Cabizza, M., Cherchi, G., Marongiu, B., Porcedda, S., Satta, M., Stassi, Isolation of a volatile concentrate of caraway seed, J. Essent. Oil Research 13 371-375 (2001).

[10] I. Papamichail, V. Louli, K. Magoulas, Supercritical fluid extraction of celery seed oil, Supercrit. Fluids 18, 213-226 (2000).

[11] E. Daukšas, P.R. Venskutonis, B. Sivik, T. Nillson, Effect of fast $\mathrm{CO}_{2}$ pressure changes on the yield of lovage (Levisticum officinale Koch.) and celery (Apium graveolens L.) extracts, J. Supercrit. Fluids 22, 201-210 (2002).

[12] H. Liu, Ch. Liu, B. Li, Research on extraction and separation of oil from celery seeds by supercritical fluid extraction method, Science and Technology of Food Industry 6, (2008).

[13] B. Marongiu, A. Piras, S. Porcedda, E. Tuveri, E. Sanjust, M. Meli, F. Sollai, P. Zucca, A. Rescigno, Supercritical $\mathrm{CO}_{2}$ Extract of Cinnamomum zeylanicum: Chemical characterization and antityrosinase activity, J. Agric. Food Chem. 55, 1002210027 (2007)

[14] B. Huang, Y. Liu, Y. Chen, Y.Q. Liao, Study on extraction of cinnamon oil by supercritical carbon dioxide, Chem. \& Industry of Forest Products 23, 59-62 (2003).

[15] S. Zhao, H. Liang, Study of extraction of cinnamon oils from the bark of Cinnamomum cassia Presl by supercritical carbon dioxide, Polish J. of Chem. 80, 99-105 (2006).

[16] G. Della Porta, R. Taddeo, E. D’Urso, E. Reverchon, Isolation of clove bud and star anise essential oil by supercritical $\mathrm{CO}_{2}$ extraction, Lebensm. 1-Wiss.Technol. 31, 454-460 (1998).

[17] W. Guan, Sh. Li, R. Yan, Sh. Tang, C. Quan, Comparison of essential oils of clove buds extracted with supercritical carbon dioxide and other three traditional extraction methods, Food Chem. 101, 1558-1564 (2007).

[18] F. Yazdani, M. Mafi, F. Farhadi, K. Tabar-Heidar, K. Aghapoor, F. Mohsenzadeh, H. R. Darabi, Supercritical $\mathrm{CO}_{2}$ extrcation of essential oil from clove bud: Effect of operation conditions on the selective isolation of eugenol and eugenyl acetate, Zeitschrift für Naturforschung - Section B, J. Chem. Sci. 60, 1197-1201 (2005).

[19] G. Anitescu, C. Doneanu, V. Radulescu, Isolation of coriander oil: Comparison between steam distillation and supercritical $\mathrm{CO}_{2}$ extraction, Flavour Fragr. J. 12, 173-176 (1997).

[20] V. Illés, H.G. Daood, S. Perneczki, L. Szokonya, M. Then, Extraction of coriander seed oil by $\mathrm{CO}_{2}$ and propane at super- and subcritical conditions, $J$. of Supercrit. Fluids 17, 117-186 (2000).

[21] C. Grosso, V. Ferraro, A.C. Figueiredo, J.G. Barroso, J.A. Coelho, A.M. Palavra, Supercritical carbon dioxide extraction of volatile oil from Italian coriander seeds, Food Chem. 111, 197-203 (2008).

[22] B. Yepez, M. Espinosa, S. López, G. Bolaos, Producing antioxidant fractions from herbaceous matrices by supercritical fluid extraction, Fluid Phase Equil. 94-197, 879-884 (2002).

[23] S. H. Beis, N. T. Dunford, Supercitical fluid extraction of daphne (Laurus nobilis L.) seed oil, JAOCS 83, 953-957 (2006).

[24] H. Marzouki, A.Piras, B. Marongiu, A.Rosa, M. A. Dessì, Extraction and separation of volatile and fixed oils from berries of Laurus nobilis L. by supercritical $\mathrm{CO}_{2}$, Molecules 13, 1702-1711 (2008).

[25] B. Simándi, A. Deák, E. Ronyái, Y. Gao, T. Veress, E. Lemberkovics, M. Then, A. Sass-Kiss, Z. Vamos Falusi, Supercritical carbon dioxide extraction and fractionation of fennel oil J. Agric. Food 
Chem. 47, 1365-1640 (1999).

[26] B. Damjanović, Ž. Lepojević, V. Živković, A. Tolić, Extraction of fennel (Foeniculum vulgare Mill.) seeds with supercritical $\mathrm{CO}_{2}$ : Comparison with hydrodistillation, Food Chem. 92, 43-149 (2005).

[27] J. Reverchon, C. Daghero, M. Marrone, M. Mattea, M. Polleto, Supercritical fractional extraction of fennel seed oil and essential oil: Experiments and mathematical modeling, Ind. Eng. Chem. Res. 38, 3069-3075 (1999).

[28] F. Yamini, S.M. Sefidkon, Pourmortazavi, Comparison of essential oil composition of Iranian fennel (Foeniculum vulgare) obtained by supercritical carbon dioxide extraction and hydrodistillation methods, Flavour Fragr. J. 17, 345-348 (2002).

[29] K. Kerrola, B. Galambosi, H. Kalliot, Volatile components and odor intensity of four phenotypes of hyssop (Hyssopus officinalis L.), J. Agric. Food Chem. 42, 776-781 (1994).

[30] H. Kazazi, K. Rezaei, S. J. Ghotb-Sharif, Z. Emam-Djomeh, Y. Yamini, Supercriticial fluid extraction flavors and fragrances from Hyssopus officinalis L cultivated in Iran, Food Chem. 105, 805-811 (2007).

[31] E. Langa, J. Cacho, AS.M.F. Palavra, J. Burillo, A.M. Mainar, J.S. Urieta, The evolution of hyssop oil composition in the supercritical extraction curve. Modelling of the oil extraction process, $J$. Supercrit. Fluids 49, 37-44 (2009).

[32] K.C. Zancan, M.O.M. Marques, A.J. Petenate, M.A.M. Meireles, Extraction of ginger (Zingiber officinale Roscoe) oleoresin with $\mathrm{CO}_{2}$ and cosolvents: Study of the antioxidant action of the oil extracts, J. Supercrit. Fluids 24, 57-76 (2002).

[33] J. Martínez, A.R. Monteiro, P.T.V. Rosa, M.O.M. Marques, M. Angela, A. Meireles, Multicomponent Model to Describe Extraction of Ginger Oleoresin with Supercritical Carbon Dioxide, Ind. Eng. Chem. Res. 42, 1057-1063 (2003).

[34] B. Barjaktarović, M. Sovilj, Ž. Knez, Supercritical fluid extraction of Juniperus communis L., Proceedings of the 6th International Symposium "Interdisciplinary Regional Research", October 3-4, 2002, Novi Sad, Yugoslavia, p. S4-428.

[35] B. Barjaktarović, Ž. Knez, M. Sovilj, Extraction of Juniperus communis L. with supercritical carbon dioxide, Proceedings of the 4th European Congress of Chemical Enginering, Sept. 20-22, 2003,
Granada, Spain

[36] B. Barjaktarović, Ž. Knez, M. Sovilj, Extraction of Juniperus communis L. with supercritical carbon dioxide, Proceedings of the 4th European Congress of Chemical Engineering, September 20-22, 2003, Granada, Spain. CD-ROM, P-12.2-011.

[37] B. Barjaktarović, M. Sovilj, Ž. Knez, Chemical composition of Juniperus communis L. fruits supercritical $\mathrm{CO}_{2}$ extracts: Dependence on pressure and extraction time, J. Agric. Food Chem. 53, 2630-2636 (2005).

[38] B.G. Nikolovski, Kinetics and mathematical modeling of juniper berry (Juniper communis L.) essential oil and pumpkin seed (Cucurbita pepo L.) oil by supercritical carbon dioxide, Ph.D. Thesis, University of Novi Sad, Faculty of Technology, Novi Sad, Serbia, 2009.

[39] B.Marongiu, S. Porcedda, A. Piras, G. Sanna, M. Murreddu, R. Loddo, Extraction of essential oil by supercritical carbon dioxide Juniperus communis L. ssp. nana Willd, Flavour Fragr. J. 21, 148-154 (2006).

[40] B. Damjanović, D. Skala, J. Baras, D. PetrovićDjakov, Isolation of essential oil and supercritical carbon dioxid extract of Juniperus communis L. fruits from Montenegro, Flavour Fragr. J. 21, 875-880 (2006).

[41] E. Reverchon, G. Della Porta, G.F. Senatore, Supercritical $\mathrm{CO}_{2}$ extraction and fractionation of lavender essentiall and waxes, J. Agric. Food Chem. 43, 1654-1658 (1995).

[42] C. Da Porto, D. Decorti, I. Kikić, Flavour compounds of Lavandula angustifolia L. to use in food manufacturing: Comparison of three different extraction methods, Food Chem. 12, 1072-1078 (2009).

[43] M. Akgün, N.A. Akgün, S. Dinçer, S., Extraction and modeling of lavender flower essential oil using supercritical carbon dioxide, Ind. Eng. Chem. Res. 39, 473-477 (2000).

[44] E. Vági, B. Simándi, A. Suhajda, Ė. Héthely. Essential oil composition and antimicrobial activity Origanum majorana L. extracts obtained with ethyl alcohol and supercritical carbon dioxide, Food Res. Internat. 38, 51-57 (2005).

[45] M.R.A. Rodriges, L.C. Krause, E.B.C. Jonathan, G. dos Santos, C.D., J.V. De Oliviera, Chemical Composition and Extraction Yield of the Extract of Origanum vulgare Obtained from Sub- and Super- 
critical $\mathrm{CO}_{2}$, J. Agric. Food Chem. 52, 3042-3047 (2004).

[46] E. Vágy, B. Simándi, H.G. Daood, A. Deak, J. Sawinski, Recovery of pigments from Origanum majorana L. Extraction with supercritical carbon dioxide, J. Agric. Food Chem. 50, 2297-2301 (2002).

[47] N. Aghel, Y. Yamini, A. Hadjiakhoondi, S. M. Pourmortazavi, Supercritical carbon dioxide extraction of Mentha pulegium L. essential oil, Talanta 62, 407-411 (2004).

[48] E.M.C. Reis-Vasco, J.A.P. Coelho, A.M.F. Palavra, Comparison of pennyroyal oils obtained by supercritical $\mathrm{CO}_{2}$ extraction and hydrodistillation. Flavour Fragr. J. 14, 156-160 (1999).

[49] H.G. Daood, V. Illés, M.H. Gnayfeed, B. Mészáros, G. Horváth, P. Biacs, Extraction of pungent spice paprika by supercritical carbon dioxide and subcritical propane, J. Supercrit. Fluids 23, 143-152 (2002).

[50] E. Uquiche, J.M. del Valle, J. Ortiz, Supercritical carbon dioxide extraction of red pepper (Capsicum annuum L.) oleoresin, J. Food Eng. 65, 55-66 (2004).

[51] X. Han, L. Cheng, R. Zhang, J. Bi, Extraction of safflower seed oil by supercritical $\mathrm{CO}_{2}, \mathrm{~J}$. Food Eng. 92, 370-376 (2009).

[52] X.J. Han, R. Zhang, J.C. Bi, Extraction of essential oil and carthamin from safflower dreg with supercritical $\mathrm{CO}_{2}$, Guocheng Gongcheng Xuebao /The Chinese J. Proc. Eng. 9, 689-694 (2009).

[53] S.A. Aleksovski, H. Sovová, Supercritical $\mathrm{CO}_{2}$ extraction of Salvia officinalis L., J. Supercrit. Fluids 40, 239-245 (2007).

[54] C. Glišić, J. Ivanović, M. Ristić, D. Skala, D., Extraction of sage (Salvia officinalis L.) by supercritical $\mathrm{CO}_{2}$ : Kinetic data, chemical composition and selectivity of diterpenes, J. Supercrit. Fluids 52, 62-70 (2010).

[55] M.E.M. Braga, M.A.A. Meireles, Accelerated solvent extraction and fractioned extraction to obtain the Curcuma longa volatile oil and oleoresin, J. Food Process Eng. 30, 501-521 (2007).
[56] B. Gopalan, B., M. Goto, A. Kodama, T. Hirose, Supercritical carbon dioxide extraction of turmeric (Curcuma longa), J. Agric. Food Chem. 48, 21892192 (2000).

[57] K. Nguyen, P. Barton, J.S. Spencer, Supercritical carbon dioxide extraction of vanilla, J. Supercrit. Fluides 4, 40-46 (1991).

[58] R.F. Rodrigues, A.K. Tashima, R.M.S. Pereira, R.S. Mohamed, F.A. Cabral, Coumarin solubility and extraction from emburana (Torresea cearensis) seeds with supercritical carbon dioxide, $J$. Supercrit. Fluids 43, 375-382 (2008).

[59] H. Sovová, Rate of the vegetable oil extract with supercritical $\mathrm{CO}_{2}$. I. Modeling of extraction curves, Chem. Eng. Sci. 49, 409-414 (1994).

[60] H. Sovová, J. Kučera, J. Jež, Rate of the vegetable oil extraction with supercritical $\mathrm{CO}_{2}$. II. Extraction of grape oil, Chem. Eng. Sci. 49, 415-420 (1994).

[61] H. Sovová, J. Jež, M. Bártlová, J. Stástová, Supercritical carbon dioxide extraction of black pepper, J. Supercrit. Fluids 8, 295-309 (1995).

[62] V.M.R., Rodrigues, P.T.V. Rosa, M.O.M. Marques, A.J. Petenate, M.A.A. Meireles, Supercritical extraction of essential oil from aniseed (Pimpinella anisum L.) using $\mathrm{CO}_{2}$ : Solubility, kinetics, and composition data, J. Agric. Food Chem. 51, 15181523 (2003).

[63] S. G. Özkal, M. E. Yener, L. Bayindirli, Mass transfer modelling of apricot kernel oil extraction with supercritical carbon dioxide, J. Supercrit. Fluids 35, 119-127 (2005).

[64] I. K. Hong, S. W. Rho, K. S. Lee, K. P. Yoo, Modeling of soybean oil bed extraction with supercritical carbon dioxide, Korean J. Chem. Eng. 7, 40-46 (1990).

[65] I. Chrastil, Solubility of solids and liquids in supercritical gases, J. Phys. Chem. 86, 3016-3021 (1982).

[66] I. Žižović, I. Stamenić, A. Orlović, D. Skala, Supercritical carbon dioxide essential oil extraction of Laminaceae family species: Mathematical modelling on the micro-scale and process optimization. Chem. Eng. Sci. 60, 6747-6756 (2005) 